\title{
Membrane Transporters for Bilirubin and Its Conjugates: A Systematic Review
}

\author{
Jovana Čvorović and Sabina Passamonti* \\ Department of Life Sciences, University of Trieste, Trieste, Italy
}

Background: Bilirubin is a highly-hydrophobic tetrapyrrole which binds to plasma albumin. It is conjugated in the liver to glucuronic acid, and the water-soluble glucuronides are excreted in urine and bile. The membrane transporters of bilirubin diglucuronide are well-known. Still undefined are however the transporters performing the uptake of bilirubin from the blood into the liver, a process known to be fast and not rate-limited. The biological importance of this process may be appraised by considering that in normal adults 200-300 mg of bilirubin are produced daily, as a result of the physiologic turnover of hemoglobin and cellular cytochromes. Nevertheless, research in this field has yielded controversial and contradicting results. We have undertaken a systematic review of the literature, believing in its utility to improve the existing knowledge and promote further advancements.

OPEN ACCESS

Edited by:

Yurong Lai,

Gilead, United States

Reviewed by:

Jaime Kapitulnik,

Hebrew University of Jerusalem, Israel

Kazuya Ishida,

University of Washington

United States

*Correspondence:

Sabina Passamonti

spassamonti@units.it

Specialty section:

This article was submitted to Drug Metabolism and Transport,

a section of the journal

Frontiers in Pharmacology

Received: 02 September 2017 Accepted: 17 November 2017 Published: 05 December 2017

Citation:

Čvorović J and Passamonti S (2017)

Membrane Transporters for Bilirubin and Its Conjugates: A Systematic Review. Front. Pharmacol. 8:887.

doi: 10.3389/fphar.2017.00887
Methods: We have sourced the PubMed database until 30 June 2017 by applying 5 sequential searches. Screening and eligibility criteria were applied to retain research articles reporting results obtained by using bilirubin molecules in membrane transport assays in vitro or by assessing serum bilirubin levels in in vivo experiments.

Results: We have identified 311 articles, retaining 44, reporting data on experimental models having 6 incremental increases of complexity (isolated proteins, membrane vesicles, cells, organ fragments, in vivo rodents, and human studies), demonstrating the function of 19 membrane transporters, encoded by either SLCO or ABC genes. Three other bilirubin transporters have no gene, though one, i.e., bilitranslocase, is annotated in the Transporter Classification Database.

Conclusions: This is the first review that has systematically examined the membrane transporters for bilirubin and its conjugates. Paradoxically, the remarkable advancements in the field of membrane transport of bilirubin have pointed to the elusive mechanism(s) enabling bilirubin to diffuse into the liver as if no cellular boundary existed.

Keywords: bilirubin, membrane, transporter, assay, systematic review

\section{INTRODUCTION}

Bilirubin (BR) is a tetrapyrrolic pigment found in plasma as an albumin-bound reversible complex (Jacobsen and Brodersen, 1983). It derives from catabolism of heme, released by both hemoglobin (75\%) and cytochromes (25\%), with a daily production of about $200-300 \mathrm{mg}$ in a normal adult (Levitt and Levitt, 2014). The liver is the organ where BR is taken up, metabolized by glucuronoconjugation, and excreted into the bile (Sticova and Jirsa, 2013). 
In the liver, the membrane transport mechanisms of BR have distinctive features, depending on the BR molecule (conjugated or not), the plasma membrane interface (vascular or biliary), and the bioenergetics of transport (to electrochemical equilibrium or not).

Considering sinusoidal uptake of BR, the liver has the capacity to take up as much as $50 \%$ of a BR load in a single pass (Stollman et al., 1983) by a process that shows substrate saturation and competitive inhibition by other organic anions, like indocyanine green and bromosulfophthalein (BSP) (Hunton et al., 1961; Scharschmidt et al., 1975; Bloomer and Zaccaria, 1976). This is evidence for a transporter-mediated process. Considering transport of conjugated BR from the liver parenchyma to the bile, it is rate-limiting, not inhibited by BR (Goresky, 1965), and energy-dependent (Nakatani et al., 1995).

Genetic diseases have shed light on the membrane transporters for BR and its conjugates (Erlinger et al., 2014; Keppler, 2014) The Dubin-Johnson syndrome is caused by mutations in the protein MRP2, encoded by $A B C C 2$, which drastically reduce the capacity of the liver to excrete the conjugated pigment into the bile. The sister protein MRP3, encoded by $A B C C 3$, is expressed at the sinusoidal membrane and pumps bilirubin diglucuronide (BDG) back into the blood, which leads to conjugated hyperbilirubinaemia. Rotor syndrome is characterized by defective reuptake of BDG from the blood into the liver by OATP1B1/OATP1B3, encoded by SLCO1B1/1B3 (Keppler, 2014) and is known as a predominantly conjugated hyperbilirubinemia.

The Gilbert's syndrome is characterized by familial unconjugated hyperbilirubinemia, due to UGT1A1 mutations causing defective conjugation of BR with glucuronic acid in the liver. However, defects of hepatic uptake transporters might contribute to pathogenesis, as pointed out in a study on subjects displaying the Gilbert's syndrome but no UGT1A1 mutations (Skierka et al., 2013).

Technical, biological and conceptual issues have contrasted the progress of knowledge about the transporter-mediated diffusion of unconjugated bilirubin (UCB) across biological membranes. These are the insolubility and instability of BR in aqueous media (McDonagh, 2008), the very fast rate of transport (Billing and Black, 1969), the property of organic anion transporters, such as OATPs, to handle a large number of different drugs, metabolites or phytochemicals (Hagenbuch and Stieger, 2013) and, not least, a steady confidence in the occurrence of a single transporter protein performing this task.

Yet, transfer of BR across biological membranes remains one of the fundamental questions of cellular biology, at the basis of our understanding of the clinical biomarker bilirubinemia (Wang et al., 2006; Levitt and Levitt, 2014). The central question is about what makes it possible for the liver to take up $0.13-0.2 \mathrm{mg}$ $\mathrm{BR} \min ^{-1}$.

Normal fluctuations of bilirubinemia have gained momentum because mild increases are related to reduction of cardiovascular disease risk, type-2 diabetes mellitus and other conditions (Kapitulnik and Maines, 2012). Thus, it would be important to understand if membrane transporters may participate in these beneficial fluctuations, if they transport other endogenous metabolites, or plant secondary metabolites that are in our diet, or drugs, or if they can be targeted by time-dependent protein reagents resulting in up- or down-regulation, and so many other questions that other systems have already successfully addressed.

We recognized that a comprehensive review on BR-specific membrane transporters is missing in the literature. In the attempt to fill this deficit, we have undertaken a systematic review of the literature, believing in its utility to both improve the existing knowledge and promote a rational planning of new investigations.

We addressed some fundamental research questions, common to any experimental study about membrane transport, such as the following.

\section{What Transporters Catalyze Translocation of Bilirubin across Biological Membranes?}

This was a primary research question and one of the criteria for eligibility.

\section{What Experimental Model Was Used to Assess Bilirubin Transport, Either in Vivo or in Vitro?}

It is important to have a survey of the methods used and the related results, possibly independently obtained by different research groups. It is a question relevant for the case of the reproducibility, usability and predictability of available research results. We searched for protein, vesicles/liposomes, isolated cells, tissue fragments, isolated organs, in vivo animals, and clinical trials.

\section{What Bilirubin Molecule Was Used in in Vitro Assays?}

This was a primary research question and one of the criteria for eligibility. Both $\mathrm{BR}$ and its conjugated derivatives were considered, because both are transported by transportermediated mechanisms.

\section{What Bilirubin Concentrations Were Used in Transporter Activity Assays?}

The concentration conditions selected for the in vitro studies were clearly relevant for the quality of the data, not only because an assay that used physiological concentrations of transport substrate or modulator had a higher predictability power, but also because of chemical stability of BR.

\section{Was Bilirubin Used as a Substrate or as a Modulator of Transporter Activity?}

Direct analysis of a transport substrate is the preferred approach in any assay. However, the poor water solubility of BR (i.e., the albumin-free, unconjugated species), its relevant physiological concentration in the $\mathrm{nM}$ range, and its time-dependent chemical decay limit the versatility of BR-based transport assays. By exploiting the principles of inhibition kinetics, it is possible to use an alternate transport substrate in the presence of BR as a transporter modulator (typically a competitive inhibitor) and so to estimate the properties of the transporter-BR interaction(s). 


\section{What Competing Molecules Interfere with Bilirubin Transporters?}

Knowledge of the molecules competing with BR for membrane transport sheds light on both fundamental aspects of BR metabolism and its value as a serum biomarker. Furthermore, this question concerns methodological issues, since some of these competing molecules might be used in activity assays of BR-specific membrane transporters.

\section{MATERIALS AND METHODS}

We have implemented the PRISMA guidelines to retrieve, select and analyze primary research articles reporting results on BR membrane transporters (Shamseer et al., 2015).

\section{Identification of Articles in Public Database Information Sources}

We have chosen to search only PubMed, because it is the benchmark repository of biomedical literature. Though it can be considered that different databases have different algorithms to process queries and apply filters, this review has disregarded the point of managing, comparing and discussing differences in the performance of search process among different databases.

We searched PubMed in four sequential search steps, as described in Table 1.

\section{Search Strategy}

The time window was open, with the first paper dated 1970June 2017. Filters were not applied. The term transporter was chosen because it is a standard term that defines a protein entity associated with membrane transport function, corresponding to the MeSH Heading Membrane Transport Proteins (U.S. National Library of Medicine).

The output of each search step was a set of automatically identified articles. The second, third and fourth searches contained duplicate articles that were immediately removed. The fifth search was manual.

\section{Selection of Eligible Articles}

\section{Selection Strategy}

The articles identified by the sequential search steps were selected by reading the abstract and/or the full text. Criteria for retaining
(IN) or discarding (OUT) are detailed in Table 2. As a result of screening, selected articles underwent a more stringent eligibility check, which retained articles eligible for the analysis and classification of their study features.

\section{RESULTS}

\section{Literature Search and Selection}

Figure 1 shows the literature search strategy and the results obtained at each of the five steps of the selection process.

The 1st search identified 149 article titles. Screening and eligibility check enabled to include 24 articles in the review.

After this first step, we realized the limitations of the search query, since some of the seminal papers on BR membrane transport were not present among identified records (e.g., Stremmel et al., 1983; Cui et al., 2001; Briz et al., 2003). Therefore, we decided to perform a sequence of query-based searches, in order to refine our search strategy and possibly retrieve missing articles.

In the 2nd and 3rd search phases (Figure 1), the term "transporter" was substituted with either "carrier protein," a popular term in pre-genomic times, or the more restrictive term "organic anion transporter." We retrieved 158 and 78 records, respectively, but only 2 were included in the final analysis. Nevertheless, some classic papers were still missing (Cui et al., 2001; Briz et al., 2003), raising the concern that some others might have been left behind.

The 4th search phase was more straightforward, using the names of $\mathrm{BR}$ membrane transporter proteins described in previously retrieved articles, such as OATP, MRP, MDR or bilitranslocase. It identified 215 articles, of which 14 were included in the review.

The last phase was the manual retrieval of some articles that escaped the prior searches. There is no obvious reason why two articles (Cui et al., 2001; Briz et al., 2003), which are considered milestones in transporter-mediated BR uptake and determined a consolidated consensus on the role of OATP1B1 and OATP1B3 in hepatic BR uptake (Stieger and Hagenbuch, 2014), could not be retrieved, in spite of the fact that their MESH terms listed both "transporter" and "bilirubin." Similarly, other papers using BR and its conjugates as a transport substrate in accurate biochemical studies (Jedlitschky et al., 1997; Kamisako et al., 1999; Pascolo

TABLE 1 | Search strategy.

\begin{tabular}{|c|c|c|}
\hline \# & Search & Rationale \\
\hline 1st & $\begin{array}{l}\text { Bilirubin AND membrane AND transporter } \\
\text { AND assay }\end{array}$ & $\begin{array}{l}\text { Bilirubin is the tested molecule used in biological assays that measure the activity of a given membrane } \\
\text { transporter. }\end{array}$ \\
\hline 3rd & $\begin{array}{l}\text { Bilirubin AND membrane AND organic } \\
\text { anion transporter AND assay }\end{array}$ & $\begin{array}{l}\text { Search \#3 is the same as search \#1, except for using the MESH term Organic Anion Transporter instead of } \\
\text { Transporter. Organic anions include bilirubin. }\end{array}$ \\
\hline 5th & Manual & $\begin{array}{l}\text { Retrieval of articles that have escaped query-based searches, in spite of being indexed by MeSH terms such } \\
\text { as "transporter" and "bilirubin". }\end{array}$ \\
\hline
\end{tabular}


TABLE 2 | Selection strategy.

\begin{tabular}{|c|c|c|c|c|}
\hline Phase & Text & In & Out & Results \\
\hline Screening & $\begin{array}{l}\text { Abstract (with Materials } \\
\text { and Methods, if } \\
\text { needed) }\end{array}$ & $\begin{array}{l}\text { - Primary/original research articles } \\
\text { - Using mammalian experimental models for } \\
\text { studying membrane transporters } \\
\text { - Using bilirubin }\end{array}$ & $\begin{array}{l}\text { - Not in English } \\
\text { - Reviews } \\
\text { - Not performed in mammalian models } \\
\text { - Not using mammalian genetic material } \\
\text { - Not reporting results on bilirubin analysis } \\
\text { in biological or physiological fluids } \\
\text { - Not reporting results on biological } \\
\text { transport assays }\end{array}$ & $\begin{array}{l}\text { Articles screened for further } \\
\text { eligibility check }\end{array}$ \\
\hline Eligibility check & Full text & $\begin{array}{l}\text { - The article section "Materials and Methods" } \\
\text { describes: (a) a biological assay to assess } \\
\text { membrane transport activity using bilirubin } \\
\text { as either substrate or modulator; (b) } \\
\text { chemical analysis of bilirubin in bio-fluids or } \\
\text { tissue extracts. } \\
\text { - The article section "Results" (including } \\
\text { Figures and Tables) reports experimental } \\
\text { data about transport and distribution of } \\
\text { bilirubin in compartments separated by } \\
\text { biological membranes. }\end{array}$ & $\begin{array}{l}\text { - Bilirubin transport was just hypothesized } \\
\text { on the basis of existing literature } \\
\text { - Bilirubin was tested as inducer of the } \\
\text { expression of membrane transporters, } \\
\text { without experimental proof of change in } \\
\text { bilirubin transport activity or distribution } \\
\text { in compartments } \\
\text { - Mutated forms of membrane } \\
\text { transporters were tested, without } \\
\text { experimental proof of change in bilirubin } \\
\text { transport activity }\end{array}$ & $\begin{array}{l}\text { Included articles as eligible } \\
\text { for the analysis of their study } \\
\text { features (STEP } 3 \text { of the } \\
\text { systematic review) }\end{array}$ \\
\hline
\end{tabular}

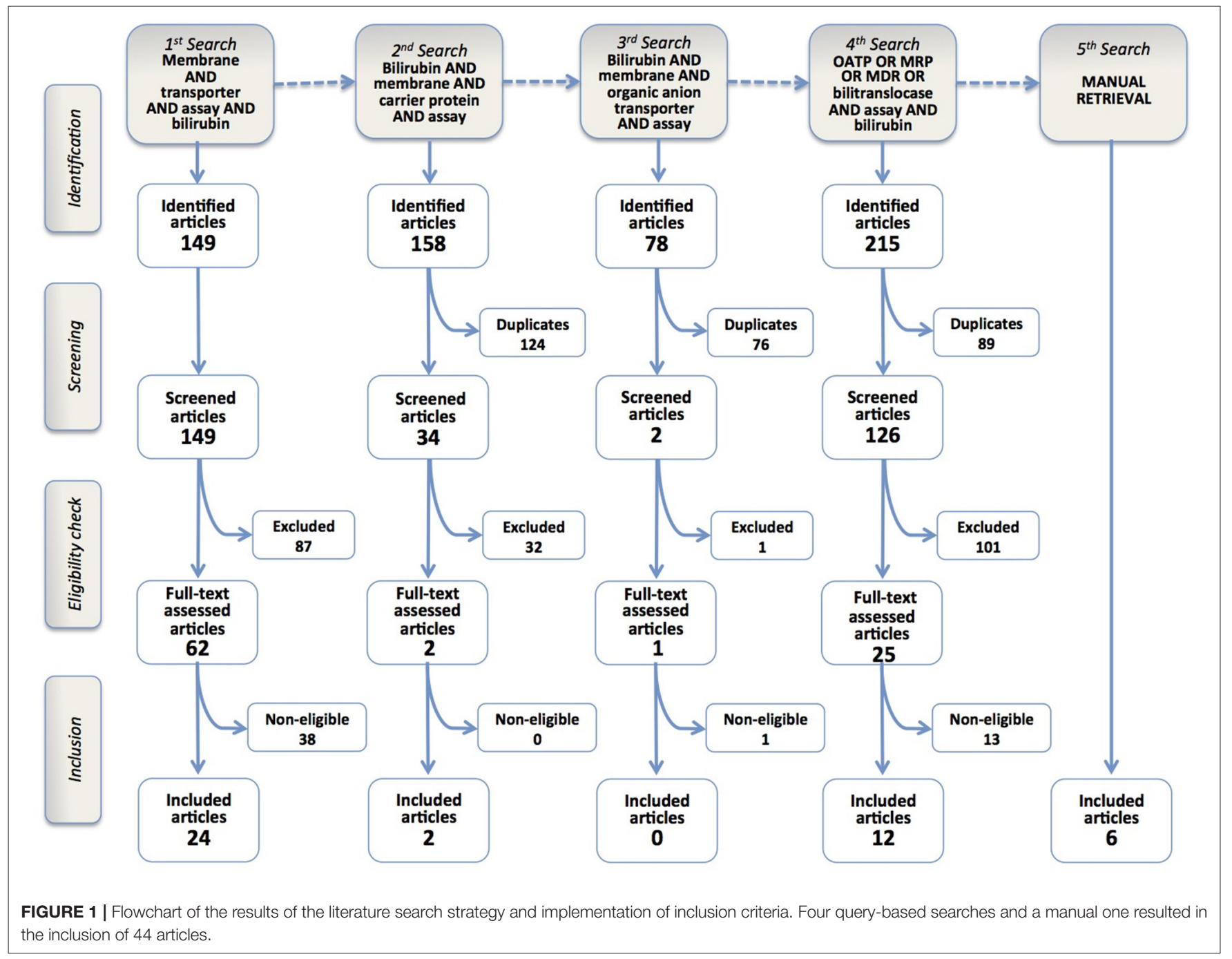


et al., 2001; Rigato et al., 2004) remained out. Other articles, reporting in vivo studies with drug transporter-deficient mouse models with hypebilirubinemic phenotypes (Chen et al., 2008; Lu et al., 2008) were lost but, in these cases, their MeSH terms did not mention BR, which was a constitutive element of all search queries of this review. The approach to manually retrieve these articles was to check the list of references of the included articles, or of reviews on drug and BR transporters. The manual retrieval of articles was however kept to the least possible extent, even if this implied the risk of overlooking some articles. In fact, manual retrieval is neither systematic nor automatic, i.e., it is not reproducible, since it stems from individual experience, curiosity or perspicacity. By contrast, this review aims at offering a universal "baseline" of current knowledge on BR membrane transporters and a method to update it and so measure the future progress in the field.

\section{Features of Bilirubin Membrane Transport Studies}

The 44 papers to be analyzed were then classified in two groupsin vitro and in vivo studies, according to the experimental model used to study BR transport. These studies are briefly described below, with limited reference to other items of literature.

\section{In Vitro Studies on Membrane Transport of Bilirubin}

The list of in vitro transport studies is reported in Table 3. Assays used BR molecules either as transport substrates or as transport modulators added to the assay mixture containing dyes, drugs or metabolites. The dye sulfobromphthalein (BSP), used in hepatic functional tests (Burra and Masier, 2004), has been applied in pioneering pharmacokinetic experiments that demonstrated the capacity of BR to inhibit BSP clearance in rats (Scharschmidt et al., 1975).

\section{Studies with Bilirubin as Substrate in Uptake Studies}

The earliest attempts at identifying the membrane transporter mediating the uptake of BR into the liver include a study (Wolkoff and Chung, 1980) on a BSP-binding membrane protein, named Organic Anion Binding Protein (OABP). It was isolated from rat liver sinusoidal plasma membrane vesicles and the direct binding with BR was measured by fluorescence spectrometry, which led to the estimation of its dissociation constant $K_{\mathrm{d}}=20 \mu \mathrm{M}$. Further cloning studies clarified that this protein was identical to a segment of the $\beta$-subunit of F1-ATPase (Goeser et al., 1990), which is well-known to have an extra-mitochondrial localization (Mangiullo et al., 2008). A dimeric BSP- and bilirubin-binding glycoprotein (BBBP) was also isolated from rat liver plasma membranes, considered to be probably related to OABP (Stremmel et al., 1983), but distinct from a third BR- and BSP-binding protein known as bilitranslocase (BTL) (Tiribelli et al., 1978). An antibody targeting BBBP inhibited the cellular uptake of BR, BDG, and BSP in the human hepatoma cell line HepG2, confirming the transporting function of this membrane protein (Stremmel and Diede, 1990), and its distinct nature from bilitranslocase (Torres et al., 1993).
The discovery of the cDNA encoding for Organic Anion Transporting Polypeptides (Jacquemin et al., 1994) opened the possibility to investigate the transport properties of members of this superfamily of solute transporters. A study (Cui et al., 2001) showed that $\left[{ }^{3} \mathrm{H}\right] \mathrm{BR}$ could be transported into human embryonic kidney cells (HEK293) stably transfected with OATP2 (OATP1B1), but not with OATP8 (OATP1B3). The apparent $\mathrm{K}_{\mathrm{m}}$ was calculated to be $160 \mathrm{nM}$. OATP1B1-mediated transport of $\mathrm{BR}$ was inhibited by BSP. These results were however questioned after assessing uptake of $\left[{ }^{3} \mathrm{H}\right] \mathrm{BR}$ into HeLa cells expressing OATP2 (i.e., OATP1B1) (Wang et al., 2003), showing that it was not different from uptake in control cells. Yet, the same transfected cells performed a marked and specific increase in uptake of BSP. It was deduced that the data reported by Cui et al. should be ascribed to unspecific binding of $\left[{ }^{3} \mathrm{H}\right] \mathrm{BR}$ on the cell membrane(s) (Wang et al., 2003). However, specific uptake of $\left[{ }^{3} \mathrm{H}\right] \mathrm{BR}$ into Xenopus oocytes expressing OATP1B1 and OATP1B3 was also reported (Briz et al., 2003).

A more recent study (Chu et al., 2015) explored the possibility to measure uptake of $\left[{ }^{3} \mathrm{H}\right] \mathrm{BR}(40 \mathrm{nM})$ into HEK293 cells stably transfected with cynomolgus OATP1B1 and OATP1B3. Though uptake of $\left[{ }^{3} \mathrm{H}\right] \mathrm{BR}$ was measurable, uptake activity was too low to use this kind of assay to kinetically characterize BR transport or to screen transporter-drug interactions.

Another study was done on cultures of human adenocarcinoma cell line (HepG2). BR was added to the extracellular medium at $50 \mathrm{nM}$ and its uptake into the cell monolayer was followed for $1.5 \mathrm{~min}$ by sampling and measuring the pigment via thermal lens spectrometry (Passamonti et al., 2005b), which exploits the thermal lens property of the pigment in solution to estimate its concentration (Franko, 2008). This analytical approach enabled to measure the progress of transfer of BR from the albumin-free medium to the cell monolayer, showing a time pattern similar to that recorded in perfused rat livers (Stollman et al., 1983). The study showed that a polyclonal antibody targeting an extracellular domain of a membrane protein bilitranslocase (Battiston et al., 1998) nearly abolished the cellular uptake of BR.

\section{Studies with Bilirubin as Substrate in Efflux Studies}

Besides the significance of BR uptake mechanisms, cellular efflux mechanisms that favor the extrusion of BR have a fundamental importance in utero. In facts, BR formed during fetal development is transferred to the maternal circulation across the cellular barrier provided by the placental trophoblast.

MRP1 is expressed at the level of the human placenta where it pumps a variety of xeno- and endobiotics back to the maternal blood (St-Pierre et al., 2000). It was identified as the most likely player in efflux of BR from cultured human trophoblast cells (BeWo cell line) used as a model of human placenta (Pascolo et al., 2001). Efflux occurred at the apical side, which is in contact with maternal blood. This study also assessed the kinetics of BR uptake into these cells, finding that it was not inhibited by taurocholate, a standard substrate of OATPs. Thus, the trophoblast cellular barrier ensures the transfer of BR from the fetal to the maternal circulation. The kinetic details of MRP1dependent BR transport were obtained in a study using plasma 
TABLE 3 | Features of included articles reporting in vitro studies.

\begin{tabular}{|c|c|c|c|c|c|c|c|}
\hline References & $\begin{array}{l}\text { Experimental model } \\
\text { description }\end{array}$ & Bilirubin molecule & [Bilirubin] & $\begin{array}{l}\text { Bilirubin- } \\
\text { transporter } \\
\text { interaction }\end{array}$ & $\begin{array}{l}\text { Competing } \\
\text { substance }\end{array}$ & Transporter & Search \# \\
\hline $\begin{array}{l}\text { Stremmel et al., } \\
1983\end{array}$ & $\begin{array}{l}\text { Rat liver plasma membrane } \\
\text { vesicles }\end{array}$ & Bilirubin & $0.2-8 \mu \mathrm{M}$ & Substrate & BSP & $\begin{array}{l}\text { Not defined-55 } \\
\text { kDa membrane } \\
\text { protein }\end{array}$ & 2nd \\
\hline $\begin{array}{l}\text { Passamonti and } \\
\text { Sottocasa, } 1990\end{array}$ & $\begin{array}{l}\text { Rat liver plasma membrane } \\
\text { vesicles }\end{array}$ & Bilirubin & $8-40 \mathrm{nM}$ & Modulator & BSP & bilitranslocase & 1st \\
\hline $\begin{array}{l}\text { Stremmel and } \\
\text { Diede, } 1990\end{array}$ & $\begin{array}{l}\text { HepG2 cells } \\
\text { (human hepato-carcinoma) }\end{array}$ & $\begin{array}{l}\text { bis-glucuronosyl } \\
\text { bilirubin }\end{array}$ & $4-48 \mu \mathrm{M}$ & Substrate & $\mathrm{BSP}$ & $\begin{array}{l}\text { Not defined-55 } \\
\text { kDa membrane } \\
\text { protein }\end{array}$ & 2nd \\
\hline $\begin{array}{l}\text { Kamisako et al., } \\
1999\end{array}$ & $\begin{array}{l}\text { Membrane vesicles from } \\
\text { HEK293 stably expressing } \\
\text { rat or human MRP2 }\end{array}$ & $\begin{array}{l}{\left[{ }^{3} \mathrm{H}\right] \text { Mono-and }} \\
\text { bis-glucuronosyl } \\
\text { bilirubin }\end{array}$ & $0.5 \mu \mathrm{M}$ & Substrate & $\begin{array}{l}\text { Leukotriene C4, } \\
\text { 17b-glucuronosyl } \\
\text { estradiol, } \\
\text { cyclosporin A }\end{array}$ & MRP2, mrp2 & 5th \\
\hline $\begin{array}{l}\text { (König et al., } \\
\text { 2000) }\end{array}$ & $\begin{array}{l}\text { HEK293 stably expressing } \\
\text { OATP1B1 }\end{array}$ & $\begin{array}{l}\text { Mono-glucuronosyl } \\
\text { bilirubin }\end{array}$ & $80 \mathrm{nM}$ & Substrate & & OATP1B1 & $1 \mathrm{st}$ \\
\hline (Cui et al., 2001) & $\begin{array}{l}\text { HEK293 permanently } \\
\text { expressing OATP1B1 or } \\
\text { OATP1B3 }\end{array}$ & $\begin{array}{l}{\left[{ }^{3} \mathrm{H}\right] \text { Bilirubin, }\left[{ }^{3} \mathrm{H}\right]} \\
\text { Mono- and }\left[{ }^{3} \mathrm{H}\right] \\
\text { Bis-glucuronosyl } \\
\text { Bilirubin }\end{array}$ & $1 \mu \mathrm{M}$ & Substrate & BSP & $\begin{array}{l}\text { OATP1B1, } \\
\text { OATP1B3 }\end{array}$ & 5th \\
\hline \multirow[t]{2}{*}{ Briz et al., 2003} & \multirow{2}{*}{$\begin{array}{l}\text { Xenopus laevis oocytes } \\
\text { expressing OATP1B1 or } \\
\text { OATP1B3 }\end{array}$} & {$\left[{ }^{3} \mathrm{H}\right]$ Bilirubin } & 0-260 nM & Substrate & & $\begin{array}{l}\text { OATP1B1, } \\
\text { OATP1B3 }\end{array}$ & 5th \\
\hline & & Bilirubin & $100 \mu \mathrm{M}$ & Modulator & $\begin{array}{l}17 \beta-\mathrm{D}- \\
\text { glucuronosyl } \\
\text { oestradiol }\end{array}$ & $\begin{array}{l}\text { OATP1B1, } \\
\text { OATP1B3 }\end{array}$ & \\
\hline Lee et al., 2004 & $\begin{array}{l}\text { Membrane vesicles from } \\
\text { MDCKIl stably expressing } \\
\text { MRP3 }\end{array}$ & $\begin{array}{l}\text { Mono-and } \\
\text { bis-glucuronosyl } \\
\text { bilirubin }\end{array}$ & $\begin{array}{l}12 \mathrm{nM} \text { (MGB), } \\
9.5 \mathrm{nM}(\mathrm{BGB})\end{array}$ & Not characterized & & MRP3 & 1st \\
\hline \multirow[t]{2}{*}{$\begin{array}{l}\text { Rigato et al., } \\
2004\end{array}$} & $\begin{array}{l}\text { Membrane vesicles from } \\
\text { MDCKII and MDCKII stably } \\
\text { expressing MRP1 and }\end{array}$ & {$\left[{ }^{3} \mathrm{H}\right]$ Bilirubin } & $6-72 \mathrm{nM}$ & Substrate & & MRP1, MRP2 & 5th \\
\hline & MRP2 & Bilirubin & $100 \mathrm{nM}$ & Modulator & Leukotriene C4 & MRP1, MRP2 & \\
\hline $\begin{array}{l}\text { Passamonti } \\
\text { et al., 2005b }\end{array}$ & HepG2 cells & Bilirubin & $50 \mathrm{nM}$ & Substrate & $\begin{array}{l}\text { Nicotinic acid, } \\
\text { BSP }\end{array}$ & bilitranslocase & $1 \mathrm{st}$ \\
\hline $\begin{array}{l}\text { Calligaris et al., } \\
2006\end{array}$ & $\begin{array}{l}\text { Primary mouse embryo } \\
\text { fibroblasts from wild type } \\
\text { and Mrp1 (-/-) mice }\end{array}$ & Bilirubin & $4-140 \mathrm{nM}$ & Substrate & & Mrp1 & 4th \\
\hline
\end{tabular}


TABLE 3 | Continued

\begin{tabular}{|c|c|c|c|c|c|c|c|}
\hline References & $\begin{array}{l}\text { Experimental model } \\
\text { description }\end{array}$ & Bilirubin molecule & [Bilirubin] & $\begin{array}{l}\text { Bilirubin- } \\
\text { transporter } \\
\text { interaction }\end{array}$ & $\begin{array}{l}\text { Competing } \\
\text { substance }\end{array}$ & Transporter & Search \# \\
\hline $\begin{array}{l}\text { Maestro et al., } \\
2010\end{array}$ & $\begin{array}{l}\text { Ea.hy } 926 \text { cells } \\
\text { (human vascular } \\
\text { endothelium) }\end{array}$ & Bilirubin & $50 \mathrm{nM}$ & Modulator & Quercetin & bilitranslocase & $1 s t$ \\
\hline $\begin{array}{l}\text { Nakanishi et al., } \\
2012\end{array}$ & $\begin{array}{l}\text { Sandwich-cultured rat } \\
\text { primary hepatocytes }\end{array}$ & Bilirubin & $\begin{array}{l}20 \mu \mathrm{M} \\
50 \mu \mathrm{M}\end{array}$ & Modulator & $\begin{array}{l}\text { CDF (5-(and 6)- } \\
\text { carboxy-2', } 7^{\prime}- \\
\text { dichlorofluorescein) }\end{array}$ & MRP2 & $1 s t$ \\
\hline $\begin{array}{l}\text { Terdoslavich } \\
\text { et al., } 2012\end{array}$ & $\begin{array}{l}\text { Human and rat liver } \\
\text { precision-cut slices }\end{array}$ & Bilirubin & $50 \mathrm{nM}$ & Modulator & $\mathrm{BSP}$ & Bilitranslocase & $1 s t$ \\
\hline Chu et al., 2015 & $\begin{array}{l}\text { HEK293 cells expressing } \\
\text { cynomolgus OATP1B1 and } \\
\text { OATP1B3 }\end{array}$ & {$\left[{ }^{3} \mathrm{H}\right]$ bilirubin } & $40 \mathrm{nM}$ & Substrate & Rifampin & $\begin{array}{l}\text { OATP1B1, } \\
\text { OATP1B3 }\end{array}$ & $1 \mathrm{st}$ \\
\hline \multirow[t]{2}{*}{$\begin{array}{l}\text { Matsushima } \\
\text { et al., } 2017\end{array}$} & $\begin{array}{l}\text { Inside-out rat erythrocyte } \\
\text { membrane vesicles }\end{array}$ & bilirubin & $10 \mu \mathrm{M}$ & Substrate & $\begin{array}{l}\text { 2,4-dinitrophenyl- } \\
\text { S-glutathione }\end{array}$ & MRPs & $1 s t$ \\
\hline & Washed rat erythrocytes & & & & & & \\
\hline
\end{tabular}

membrane vesicles prepared from human cells transfected with MRP1 $\left(\mathrm{K}_{\mathrm{m}}=10 \mathrm{nM}\right.$ and $\mathrm{V}_{\max }=100 \mathrm{pmol} \mathrm{min}^{-1} \mathrm{mg}^{-1}$ of protein) (Rigato et al., 2004). To characterize the role of Mrp1 in cellular efflux of BR and its protective effect against BRinduced cytotoxicity, mouse embryo fibroblasts from either wild type or Mrp1 knockout mice were used as a model (Calligaris et al., 2006). After $4 \mathrm{~h}$ of exposure, $\left[{ }^{3} \mathrm{H}\right] \mathrm{BR}$ accumulated more in $\mathrm{Mrp1}^{-/-}$than in wild type fibroblasts, under all conditions $(40,80$ and $140 \mathrm{nM})$. Cellular ATP levels decreased in $\mathrm{Mrp1}^{-/-}$ cells but not in normal cells. BR $(20-160 \mathrm{nM})$ was increasingly cytotoxic in both cell lines, with a stronger effect in mutant cells.

\section{Studies with Bilirubin as Modulator}

The effect of BR as modulator of transporter activity has been tested in several assays with model substrates, thus circumventing the technical difficulties of analysing BR at very low concentrations $(<0.1 \mu \mathrm{M})$ and yet taking advantage of detailed kinetic analysis of transporter-BR interaction. Using sinusoidal rat liver plasma membrane vesicles, BR $(50$ or $100 \mu \mathrm{M}$, added at $\mathrm{pH}$ 7.8) was shown to inhibit BDG transport (Adachi et al., 1990) or BSP transport (Passamonti and Sottocasa, 1990).

A complex experiment, aimed at quantitatively assess the power of BR to protect from time-dependent inhibition of bilitranslocase caused by the serine-specific reagent PMSF, enabled to obtain an apparent dissociation constant $\left(\mathrm{K}_{\mathrm{d}}=\right.$ $2.1 \mathrm{nM}$ ) of the bilitranslocase-BR complex (Passamonti et al., 1997). The same kinetic method was used to characterize the interaction of bilitranslocase with anti-sequence antibodies, obtaining the same results (Battiston et al., 1998). The ability of BR to inhibit BSP uptake was also observed with liver slices obtained from either human or rat liver; such inhibition was found to overlap with that due to bilitranslocase antibodies, but not with taurocholate, which is a substrate of OATPs but not of bilitranslocase (Terdoslavich et al., 2012). BR was also shown to inhibit the uptake of quercetin (a flavonoid molecule) into cells of the vascular endothelium (cell line Ea.hy926), expressing bilitranslocase, as assessed using antibodies (Maestro et al., 2010).
BR was also found to inhibit uptake of 2,4-Dinitrophenyl-Sglutathione, a standard substrate of MRP1, MRP2 and MRP5, in washed erythrocytes and their inside-out vesicles (Matsushima et al., 2017).

\section{Studies with Bilirubin Conjugates, Used as Substrates or Modulators}

These studies investigated the mechanism(s) responsible of either transport of conjugated BR into the bile canaliculus or their reflux from the liver into the blood.

In rat liver sinusoidal plasma membrane vesicles, uptake of bilirubin glucuronides has been characterized as sodiumindependent, electrogenic and competitively inhibited by both BSP and BR (Adachi et al., 1990). Though this function has been left without further molecular characterization, it seems that it could be performed by OATPs expressed on the sinusoidal membrane. In fact, an experiment using $\left[{ }^{3} \mathrm{H}\right] \mathrm{BMG}$ in HEK293 cells, transfected with the "SLC21A6 gene" and expressing "OATP2" protein (OATP1B1) (König et al., 2000), showed the involvement of this liver sinusoidal membrane transporter in the ATP-independent efflux to the blood of BMG and other organic anions. Later on, the same cell system was used to show that OATP1B1 transported $\left[{ }^{3} \mathrm{H}\right] \mathrm{BR}$ conjugates (Cui et al., 2001).

ATP-dependent efflux of BR conjugates also occurs at the sinusoidal membrane surface of hepatocytes, as shown in a study (Lee et al., 2004) that used plasma membrane vesicles obtained from the cell line MDCKII stably transfected with MRP3. The data support the concept that MRP3-mediated efflux of bilirubin glucuronides and other cholephilic compounds is a mechanism underlying the reflux of bile components from the liver to the blood, in situations of cholestasis.

Considering the ATP-dependent transporters expressed at the canalicular side of the liver cells, one of the pioneering studies used various plasma membrane preparations expressing human MRP1 and MRP2 and rat Mrp2, aiming at characterizing the ATP-dependent transport of both bilirubin monoglucuronide (BMG) and BDG. Furthermore, both conjugates 
were demonstrated to inhibit leukotriene transport (Jedlitschky et al., 1997), which is mediated by the same ATP-dependent primary active transporters, with $\mathrm{IC}_{50}$ values $0.1-0.7 \mu \mathrm{M}$, depending on the type of membrane preparation. A study (Kamisako et al., 1999) using membrane vesicles prepared from human cells transfected with either rat Mrp2 or human MRP2 provided the kinetic details of ATP-dependent transport of BMG and BDG $\left(\mathrm{K}_{\mathrm{m}}=0.7-0.9 \mu \mathrm{M}\right.$ and $\mathrm{V}_{\max }=255-321 \mathrm{pmol}$ $\mathrm{min}^{-1} \mathrm{mg}^{-1}$ of protein). A study using sandwich-cultured rat hepatocytes forming bile canaliculi (Nakanishi et al., 2012) confirmed that bilirubin glucuronides could inhibit the
Mrp2-mediated secretion of a fluorescein compound in the canaliculi, as detected by quantitative time-lapse imaging.

\section{In Vivo Studies on Membrane Transport of Bilirubin}

Animal models with defective expression of membrane transporters have essentially contributed to the elucidation of the mechanisms of BR uptake into the liver, excretion into the bile, and reflux from the liver to the blood. Table 4 lists in vivo transport studies.

TABLE 4 | Features of included articles reporting in vivo studies.

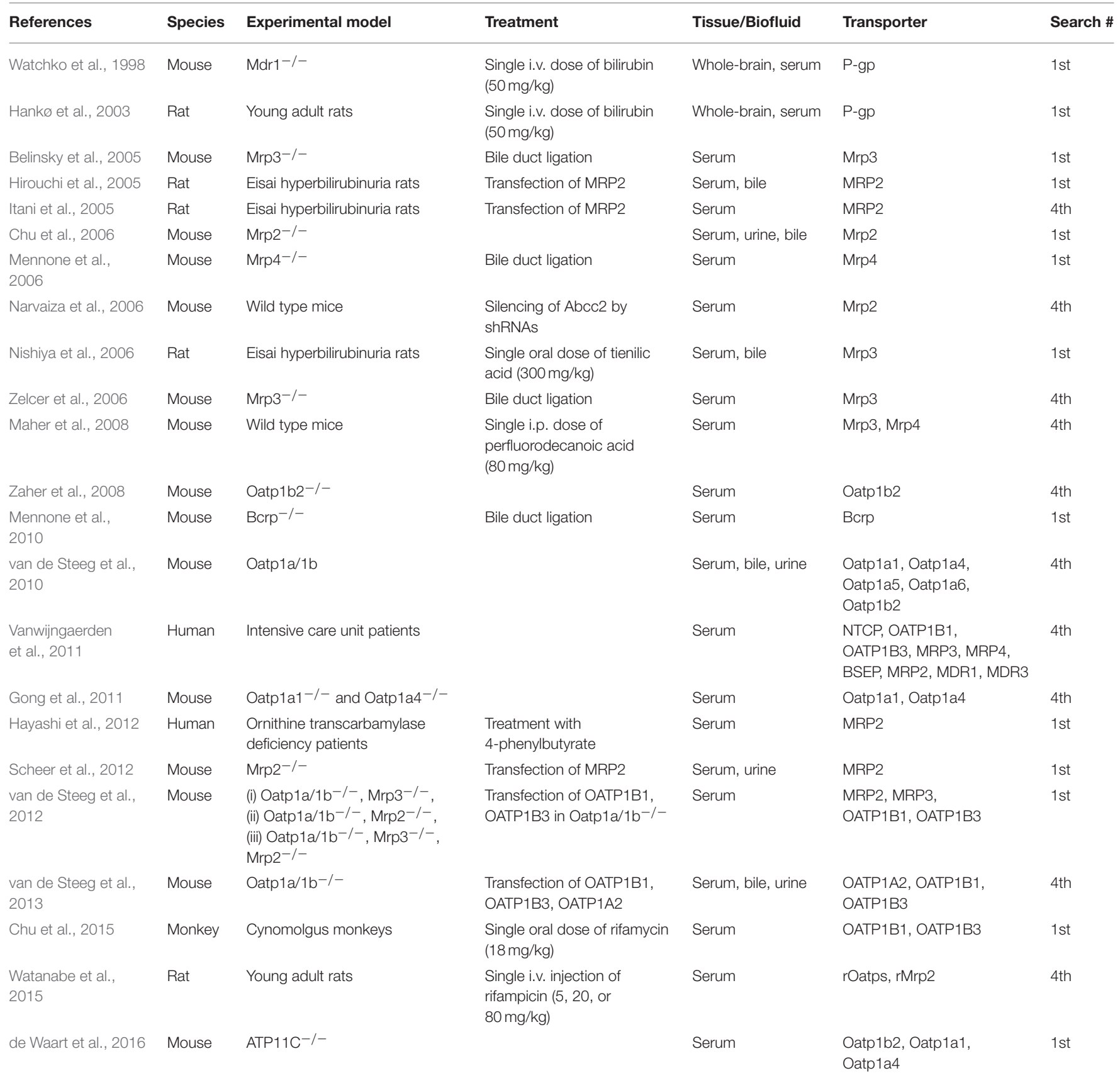




\section{Sinusoidal Uptake of Bilirubin}

Various murine models with disrupted expression of hepatic OATP transporters have been created, serving the primary need to assess their contribution to drug transport and interactions. The phenotype of these murine models has been assessed, by monitoring serum bilirubinemia, together with other biomarkers of liver pathology. Indeed, the knockout models displayed no sign of liver histopathology (Chen et al., 2008; Lu et al., 2008; Zaher et al., 2008; Gong et al., 2011) and no major change in expression of other influx or efflux transporters and P450 enzymes (Chen et al., 2008) or UDP-glucuronosyltransferase 1a1 (van de Steeg et al., 2010). In some cases, however, compensatory overexpression of other SLC transporters was noted (Lu et al., 2008).

The model mice Oatp1a1 $1^{-/-}$and Oatp1a4 $4^{-/-}$had normal clinical chemistry, i.e., no elevation of serum BR, showing that neither conjugated nor unconjugated bilirubin (UCB) is a substrate for these transporters. By contrast, sizeable changes in uptake and pharmacokinetics of some cholephilic compounds, such as estradiol 17-glucuronide (E2-17G), estradiol 3-glucuronide (E2-3G), and taurocholate, but not digoxin, were observed (Gong et al., 2011).

In rodent species, Oatp1b2 is the single ortholog that is most similar to both OATP1B1 and OATP1B3 expressed in human. The Oatp1b2-/- mouse exhibited significant loss of function with respect to drug transport, such as phalloidin and microcystin-LR (Lu et al., 2008), rifampicin, rifamycin SV, lovastatin, simvastatin, pravastatin and cerivastatin (Chen et al., 2008; Zaher et al., 2008). All studies reported just mild and stable hyperbilirubinemia, mostly due to conjugated BR (Lu et al., 2008; Zaher et al., 2008). This suggests that, under normal conditions, Oatp1b2 mediates the reuptake of conjugated BR from the blood into the liver.

A mice mutant (Slcola/1 $\mathrm{b}^{-/-}$mice), functionally deficient of all 5 Slcola (Oatp1a1,-1a4, 1a5, and-1a6) and Slcolb2 (Oatp1b2) genes, was developed to examine the joint role of these Oatp members, expressed at the absorbing surface of liver, intestinal and kidney cells, in drug pharmacokinetics and drugdrug interactions (van de Steeg et al., 2010). The only effect that loss of these proteins caused was marked hyperbilirubinemia ( $>40$-fold), with $95 \%$ of this increase due to conjugated BR. UCB increased by 2.5 times, together with unconjugated bile acids (13fold). Though bile flow was unchanged, BR excretion was half than in wild types. Altogether, these data are consistent with the view that a substantial efflux of conjugated BR by sinusoidal Mrp3 occurs, and the loss of the influx pathway caused by the cluster of Oatp1a/1b is the main cause of the observed elevated levels of conjugated BR in serum. However, this model left unanswered the question regarding the mechanisms that ensure transfer of UCB from the blood into the liver (van de Steeg et al., 2010). When this knockout mouse model was transfected with the human genes encoding for OATP1A2, OATP1B1 or OATP1B3, total and conjugated BR in serum was partially (with OATP1A2) or completely normalized (with OATP1B1 and OATP1B3) (van de Steeg et al., 2013).

Another recent study combined both genetic studies in humans and functional studies in mouse models (van de Steeg et al., 2012) to describe the mechanistic basis of Rotor syndrome (benign hereditary conjugated hyperbilirubinemia). Using knockout mice deficient in one, two or all three genes encoding for Oatp1a/1b, Mrp 2 and Mrp3, the authors demonstrated the sequential involvement of Mrp3, which promotes excretion of $\mathrm{BR}$ conjugates in the blood at the level of upstream hepatocytes, and that of Oatpla/1b, which mediates their reuptake in the downstream hepatocytes. Thus, the plasma bilirubin glucuronide levels were significantly increased in knockout mice deficient of Oatp $1 \mathrm{a} / 1 \mathrm{~b}$ alone or both Oatp1a/1b and Mrp2. By contrast, in mice deficient of both Oatpla/1b and Mrp3 these levels markedly decreased. To strengthen these findings and understand whether the corresponding human proteins act in the same way, Oatpla/1b-deficient mice were transfected so to generate transgenic mice with liver-specific expression of human OATP1B1 or OATP1B3. In both models, conjugated BR levels were normalized suggesting the reabsorption of bilirubin glucuronides by OATP1B1 and OATP1B3. These data indicate the existence of a corresponding liver-blood shuttling loop in humans with MRP3, OATP1B1 and OATP1B3 as key players in maintaining BR blood levels stable.

The ATP11C-deficient mouse is a model that displays conjugated hyperbilirubinemia and hypercholanemia, as a consequence of the defect of this P-type ATPase that catalyzes the exchange of membrane phospholipids, also known as flippase. Flipping membrane phospholipids is an essential function in bile formation. ATP11C deficiency caused decreased expression of Oatp1b2, Oatp1a1, and Oatp1a4 (de Waart et al., 2016), thus simulating the role of Oatpla/1b-knock-out mice (van de Steeg et al., 2010) and confirming that these Oatps contribute to hepatic reuptake of conjugated $\mathrm{BR}$ from the blood.

Consistently with the observation that transporter-deficient rodent models have no sign of liver pathology, except for hyperbilirubinemia, drugs that are transported by OATP and/or MRP transporters are expected to cause changes in bilirubinemia, in the absence of other signs of liver toxicity. A pharmacokinetic test done in rats with rifampicin, known for its potent and selective inhibition of Oatp transporters and a less potent effect on Mrp2, showed total serum bilirubin to increase by $62.8 \pm 12.2 \%$ and $78.3 \pm 16.0 \%$ at $1 \mathrm{~h}$ after administration of 20 and $80 \mathrm{mg} / \mathrm{kg}$ rifampicin, respectively, and these changes were due to conjugated BR (Watanabe et al., 2015). These results established the utility of serum $\mathrm{BR}$ as a sensitive and fast-responding biomarker of drugtransporter(s) interactions in pre-clinical studies. Nevertheless, a thorough analysis of a human hyperbilirubinemia dataset and the respective OATP1B1 and OATP1B3 inhibition predictions (Kotsampasakou et al., 2017a) indicated no strong association between OATP inhibition and hyperbilirubinemia, either for humans or for animals (Kotsampasakou et al., 2017b).

\section{Excretion of Conjugated Bilirubin into the Bile}

In humans, active transport of BDG in the bile is mediated by MRP2, as proven in above-mentioned in vitro studies (Jedlitschky et al., 1997; Kamisako et al., 1999). Mutations of this gene are known to cause the autosomal recessive Dubin-Johnson syndrome with mild conjugated hyperbilirubinemia. The Eisai 
hyperbilirubinemic rat (Kawaguchi et al., 1994) has a hereditary loss of Mrp2 function and is therefore an experimental model of the Dubin-Johnson syndrome.

In Eisai hyperbilirubinemic rats, i.v. injection of recombinant adenoviruses containing MRP2 resulted in the simultaneous expression of MRP2 at the hepatic canalicular membrane, recovery of normal biliary excretion of DBSP (dibromosulfophtalein) and a marked decrease of serum direct (conjugated) BR (Hirouchi et al., 2005). Similar results were obtained using a different transfecting approach consisting in an MRP2 protein-expression plasmid vector, wrapped with the hemagglutinating virus of Japan envelope protein. One day after the i.v. injection of this kit, the expression of MRP2 in the liver canalicular membrane of Eisai hyperbilirubinemic rats was normalized. This entailed normalization of expression levels of Oatp1 and Oatp2 that are downregulated in this rat strain and of MRP3 that is upregulated. As a result, serum total and conjugated BR dropped within 24 h post-transfection (Itani et al., 2005).

Adenovirus was also used as a vector to transfect mice with short hairpin RNAs targeting Mrp2 (Abcc2). This treatment caused marked down-regulation of Abcc 2 mRNA and a marked increase of total serum BR. These effects lasted several days, until the injected shRNAs were degraded (Narvaiza et al., 2006).

In $\mathrm{Mrp}^{-/-}$mice, the biliary excretion rate of $\mathrm{BDG}$ was about half than in wild types (Chu et al., 2006). However, in these knockout mice, no other efflux transporter, e.g., the sinusoidal efflux pump Mrp3, was activated by gene induction. Therefore, this mouse transgenic line corresponds to neither the Dubin-Johnson syndrome nor the Eisai hyperbilirubinemic rat. However, transfection of human MRP2 in Mrp2 $2^{-/-}$mice (Scheer et al., 2012) led to normalization of conjugated BR levels in both plasma and urine.

A study (Hayashi et al., 2012) showed that the drug 4-phenylbutyrate (4PBA) increased the cell surface expression and transport function of MRP2 in the MRP2-MDCKII cell line and of Mrp2 in the rat liver, without significantly changing the MRP2/Mrp2 mRNA level. This drug is used to manage enzyme defects of urea production, as in the syndrome known as Ornithine Transcarbamylase Deficiency (OTCD), in order to provide an alternative pathway for the excretion of excess nitrogen. Indeed, the same study observed that in OTCD patients, 4PBA increased hepatic MRP2 expression and decreased total bilirubinemia.

Another primary active transporter expressed at the canalicular side of the hepatocyte plasma membrane is the Breast cancer resistance protein (Bcrp). In Bcrp-knockout mice, no changes in serum BR were detected, showing that this protein has no relevant role in BDG excretion (Mennone et al., 2010). In these models, bile-duct ligation, which induces adaptive up-regulation of apical Mdr1 (P-gp) or sinusoidal Mrp4, did not change Bcrp expression nor serum BR. Partly different findings have been reported in an independent study (Vlaming et al., 2009), which demonstrated that Bcrp-knockout mice showed significant hyperbilirubinemia, mostly due to UCB.

\section{Reflux of Conjugated Bilirubin into the Blood in Molecular Defects of Biliary Excretion}

In case of biliary obstruction or Dubin-Johnson syndrome, the serum levels of conjugated BR increase. The identification of Mrp3 as the main sinusoidal membrane transporter responsible for the reflux of conjugated BR into the blood has been demonstrated by using either knockout mice models or by finding upregulated Mrp3 expression as a side-effect of a diuretic drug, as a toxic effect of chemicals used in industry, or in critically ill patients.

Loss of either Mrp3 or Mrp4 in $\left(^{-/-}\right)$null mutant mouse colonies caused no change of serum BR as compared to wild types. However, common bile duct ligation for 3 (Belinsky et al., 2005; Zelcer et al., 2006) or 7 days (Mennone et al., 2006) shed light on the different roles of these efflux pumps in experimental cholestasis. In Mrp3 $3^{-/-}$mice, a substantial decrease of serum conjugated BR levels was shown, as compared with controls, but levels of serum bile acids remained unchanged (Belinsky et al., 2005; Zelcer et al., 2006). By contrast, in Mrp4 $4^{-/-}$mice, serum levels of total BR did not change, whereas a 5-fold decrease of serum bile acids was observed as compared with wild type mice (Mennone et al., 2006). These findings suggested that that Mrp4 is a sinusoidal efflux transporter for bile acids, but not for bile pigments.

The same conclusion about the function of Mrp3 in promoting efflux of conjugated BR has been reached in studies aiming at clarifying the mechanism of toxicity of the diuretic drug tienilic acid (Nishiya et al., 2006). If administered to Eisai hyperbilirubinemic rats, a dose-dependent increase of total bilirubinemia coupled with up-regulation of (mRNA) Mrp3 and heme oxygenase- 1 was recorded.

Treating mice with perfluorinated carboxylic fatty acids (PCFA) induced the hepatic expression of both Mrp3 and Mrp4, which increased levels of conjugated bilirubin and total bile acids in serum. Induction was mediated by activation of both peroxisome proliferator-activated receptor alpha (PPAR $\alpha)$ and NF-E2-related factor-2 (Nrf2) (Maher et al., 2008).

Up-regulation of MRP3 and MRP4 on the sinusoidal membrane of hepatocytes was observed in post-mortem biopsies, taken from long-term critically ill patients (Vanwijngaerden et al., 2011). Liver biopsies revealed histological aspects of cholestasis. Pre-mortem blood samples showed predominantly conjugated hyperbilirubinemia and hypercholanemia. These findings consistently underline the role of these transporters in mediating active efflux of cholephilic anions into the blood.

\section{The Molecular Barrier for Bilirubin Transport into the Brain}

At the level of the blood-brain barrier, P-glycoprotein has been shown to play a role in protecting the brain from accumulation of $\mathrm{BR}$, as demonstrated by in vitro experiments reported above. The first study tested the role of P-glycoprotein in limiting the brain accumulation of BR. Thus, wild type and $\mathrm{Mdr1a}\left(^{-/-}\right)$null mutant mice received an intra-venous bolus of BR and their brain BR contents were measured 10 and $60 \mathrm{~min}$ after the infusion. Null mutants nearly doubled their brain BR, as compared to wild types (Watchko et al., 1998). This study contributed to demonstrating 
that P-glycoprotein could transport $\mathrm{BR}$ as an endogenous substrate. This observation was confirmed in experiments with wild type Sprague-Dawley rats (Hankø et al., 2003). Their brainto-plasma $\mathrm{BR}$ ratio measured after an i.v. bolus of BR was higher if it was preceded by a short $(10 \mathrm{~min})$ infusion with P-glycoprotein blockers, like propanolol, verapamil, ceftriaxone, and rifampin.

\section{DISCUSSION}

\section{Outcome of the Search Strategy}

The most unexpected outcome of having sourced PubMed by a multiphase search approach was the missing retrieval of at least 6 articles, tagged with correct $\mathrm{MeSH}$ terms.

These limitations can be overtaken by manual search, but wandering in the literature is subjective and inefficient. Another option might be the use of a different query, with "transport" instead of "transporter." However, queries should straightly reflect the goal(s) of the systematic review. This review was meant at creating a list of BR membrane transporters, with no interest in articles dealing with other biological transport phenomena, such as albumin transport of BR in the blood or non-catalyzed diffusion of BR through biological membranes. Another implication of using generic query terms is that the burden of screening and eligibility checks may obfuscate the operational value of the automatic search.

We have also noticed articles that did not list "bilirubin" as keyword or MeSH term, in spite of reporting results about its analysis, which caused them to be out of the list of included papers. Authors should therefore be aware of a proper choice of descriptors of their works.

\section{Features of Bilirubin Membrane Transport Studies}

Table 5 presents a synopsis of the outputs of our systematic review. Experimental models with increasing levels of structural and functional complexity (row 1) have been exploited to characterize the transporters (column 1) for $B R$ and its conjugates. Discovery started historically with the most reductive experimental approach, i.e., BR binding assays on an isolated protein or binding/transport in plasma membrane vesicles. In the last decade, the development of knockout/knockin rodent models has enabled to investigate the functional role of membrane transporters in vivo.

Regarding the top 2 questions asked, i.e., "what transporters ...?" and "what experimental models ...?", the extent or depth of knowledge about the listed membrane transporters can be all in all scored by the number of experimental models exploited to characterize a given transporter. Thus, rather than scoring single articles, we propose here to score the reproducibility of results on a given BR membrane transporter in multiple experimental approaches.

The champion in this review is the canalicular primary active transporter MRP2, investigated at 4 levels of biological complexity (i.e., vesicles, cells, in vivo rodent models and in humans) in 13 distinct studies. Next is the OATP cluster of sinusoidal transporters, investigated at 3 levels in 9 studies.
Third is the sinusoidal transporter bilitranslocase, investigated at 3 levels in 5 studies. The "spillover" effect of the high intensity of MRP2 studies on knowledge related to the role of basolateral efflux transporters MRP3 and MRP4 benefited from the availability of genetically modified rodent models.

\section{Membrane Transporters for Bilirubin and Its Conjugates \\ What Do We Know Now about Bilirubin Membrane Transporters?}

Table 6 lists the transporters studied in the 44 articles included in this review. With the exception of OABP and BBBP, all are annotated in the Transporter Classification Database (TCDB) (Saier et al., 2016). Of these, all but bilitranslocase have a gene name assigned by HUGO Gene Nomenclature Committee (HGNC) (Gray et al., 2015) and/or the Rat Genome Database (Shimoyama et al., 2015) and the Mouse Genome Database (Blake et al., 2017).

According to the TCDB, BR transporters are either Electrochemical potential-driven (coded as 2.A.) or Primary active (coded as 3.A.). According to HGNC, they are either solute carriers (coded as SLC) or ATP-binding cassette transporters (coded as $\mathrm{ABC}$ ).

Primary Active Transporters Mediate ATP-Dependent Cellular Efflux of Both Conjugated and Unconjugated Bilirubin

These transporters have an intracellular ATP hydrolase domain and a transport site for the unidirectional substrate translocation. Their transport substrates are chemically heterogeneous, including many drugs. It is established that MRP2 determines transport of conjugated BR from the liver into the bile at the canalicular membrane. In case of cholestasis, up-regulation of sinusoidal MRP3 determines efflux of the conjugated pigment from the liver into the blood. At the level of the placental trophoblast and the blood-brain barrier, MDR1 or MRP1 mediate efflux of UCB toward the maternal or general circulation, respectively.

\section{Electrochemical Potential-Driven Transporters Mediate Bi-Directional Transport of Bilirubin and Its Conjugates}

These transporters transfer solutes up to their electrochemical equilibrium between membrane-separated compartments. In the liver, they are expressed at the basolateral membrane domain. They have wide substrate specificity and transport drugs as well.

\section{Transporters of Conjugated Bilirubin}

OATP1B1 and OATP1B3 transport BMG and BDG from the blood into the liver. In vivo studies with transporter-deficient mice lines have demonstrated a major role of OATP1B1/1B3 (van de Steeg et al., 2010, 2012) in promoting re-uptake of conjugated bilirubin from the blood.

\section{Transporters of Bilirubin}

Less clear is the capacity of OATPs to mediate uptake of UCB from the blood into the liver. In vitro uptake studies have 
TABLE 5 | Synopsis of the experimental models used to study membrane transporters for bilirubin and its conjugates.

\begin{tabular}{|c|c|c|c|c|c|c|}
\hline Transporter & Protein & Vesicles & Cells & Tissues & Rodents in vivo & Primates in vivo \\
\hline Unknown & & Adachi et al., 1990 & & & & \\
\hline $\begin{array}{l}\text { Organic Anion } \\
\text { Binding Protein }\end{array}$ & $\begin{array}{l}\text { Wolkoff and } \\
\text { Chung, } 1980\end{array}$ & & & & & \\
\hline $\begin{array}{l}\text { BSP/bilirubin } \\
\text { binding protein }\end{array}$ & & Stremmel et al., 1983 & $\begin{array}{l}\text { Stremmel and Diede, } \\
1990\end{array}$ & & & \\
\hline Bilitranslocase & & $\begin{array}{l}\text { Passamonti and } \\
\text { Sottocasa, 1990; } \\
\text { Passamonti et al., } 1997\end{array}$ & $\begin{array}{l}\text { Passamonti et al., } \\
\text { 2005b; Maestro et al., } \\
2010\end{array}$ & $\begin{array}{l}\text { Terdoslavich et al., } \\
2012\end{array}$ & & \\
\hline $\begin{array}{l}\text { OATP1A2, } \\
\text { OATP1B1 } \\
\text { /OATP1B, } \\
\text { Oatp1b2 }\end{array}$ & & & $\begin{array}{l}\text { König et al., 2000; Cui } \\
\text { et al., 2001; Briz et al., } \\
\text { 2003; Wang et al., } \\
\text { 2003; Chu et al., } 2015\end{array}$ & & $\begin{array}{l}\text { Chen et al., 2008; Lu et al., } \\
\text { 2008; Zaher et al., 2008; } \\
\text { van de Steeg et al., 2010, } \\
\text { 2012, 2013; Watanabe } \\
\text { et al., 2015; de Waart et al., } \\
2016\end{array}$ & $\begin{array}{l}\text { Vanwijngaerden } \\
\text { et al., 2011; Chu } \\
\text { et al., } 2015\end{array}$ \\
\hline MRP1, Mrp1 & & $\begin{array}{l}\text { Jedlitschky et al., 1997; } \\
\text { Rigato et al., 2004; } \\
\text { Matsushima et al., } \\
2017\end{array}$ & $\begin{array}{l}\text { Pascolo et al., 2001; } \\
\text { Calligaris et al., } 2006\end{array}$ & & & \\
\hline Mdr1/P-gp & & & & & $\begin{array}{l}\text { Watchko et al., 1998; } \\
\text { Hankø et al., 2003; } \\
\text { Mennone et al., } 2010\end{array}$ & \\
\hline MRP2, Mrp2 & & $\begin{array}{l}\text { Jedlitschky et al., 1997; } \\
\text { Kamisako et al., 1999; } \\
\text { Rigato et al., 2004; } \\
\text { Matsushima et al., } \\
2017\end{array}$ & $\begin{array}{l}\text { Nakanishi et al., 2012; } \\
\text { Matsushima et al., } \\
2017\end{array}$ & & $\begin{array}{l}\text { Hirouchi et al., 2005; Itani } \\
\text { et al., 2005; Chu et al., } \\
\text { 2006; Narvaiza et al., 2006; } \\
\text { Scheer et al., 2012; van de } \\
\text { Steeg et al., 2012; } \\
\text { Watanabe et al., } 2015\end{array}$ & $\begin{array}{l}\text { Hayashi et al., } \\
2012\end{array}$ \\
\hline Oatp1a1/Oatp1a4 & & & & & $\begin{array}{l}\text { van de Steeg et al., 2010; } \\
\text { Gong et al., 2011; de Waart } \\
\text { et al., } 2016\end{array}$ & \\
\hline Bcrp & & & & & Mennone et al., 2010 & \\
\hline MRP3, Mrp3 & & Lee et al., 2004 & & & $\begin{array}{l}\text { Belinsky et al., 2005; Nishiya } \\
\text { et al., 2006; Zelcer et al., } \\
\text { 2006; Maher et al., 2008; } \\
\text { van de Steeg et al., } 2012\end{array}$ & $\begin{array}{l}\text { Vanwijngaerden } \\
\text { et al., } 2011\end{array}$ \\
\hline Mrp4 & & & & & $\begin{array}{l}\text { Mennone et al., 2006; } \\
\text { Maher et al., } 2008\end{array}$ & $\begin{array}{l}\text { Vanwijngaerden } \\
\text { et al., } 2011\end{array}$ \\
\hline MRP5 & & $\begin{array}{l}\text { Matsushima et al., } \\
2017\end{array}$ & $\begin{array}{l}\text { Matsushima et al., } \\
2017\end{array}$ & & & \\
\hline
\end{tabular}

The transporters are listed according the publication date of articles first reporting relevant studies.

produced contradicting results, with evidence both in favor (Cui et al., 2001; Briz et al., 2003) and against (Pascolo et al., 2001; Wang et al., 2003) the hypothesis that UCB is a substrate of certain OATPs.

Population studies showed that single-nucleotide polymorphisms of either the gene SLCO1B1 or the gene $S L C 1 B 3$ are associated with mild elevations of conjugated BR (Zhang et al., 2007; Sanna et al., 2009) or UCB (Sanna et al., 2009) in serum, respectively.

A deeper study with transgenic mice expressing OATP1B1/1B3/1A2 (van de Steeg et al., 2013) provided evidence in support of the concept that OATPs play a limited role in uptake of UCB into the liver.

Also, studies on the ontogeny of hepatic drug transporters (Mooij et al., 2014) indicated that the mRNA expression of OATP1B1 and OATP1B3 is 500-600-fold lower in human neonates than in adults. Considering that in neonates there is a rise of $\mathrm{UCB}$ in serum, it may be suggested that alternative membrane transporters for $\mathrm{BR}$ should be responsible for bilirubin uptake into the liver.

Furthermore, analyses of hepatic toxicity in humans and animals did not indicate strong association between OATP inhibition and hyperbilirubinemia, neither for humans nor for animals (Kotsampasakou et al., 2017b).

This does not mean that OATPs have little to do with membrane transport of bile pigments. First, their apparent limited role in determining UCB levels in serum might just indicate that $\mathrm{BR}$ and $\mathrm{BDG}$ are mutually competing for transport by OATPs, with prevailing affinity and occupancy of BDG in the transporter active site. Further clues might be found in other domains of the natural sciences. Two studies have shown that expression of OATP1B3 in the hen's oviduct and the shell 
TABLE 6 | Membrane transporters of bilirubin and its conjugates.

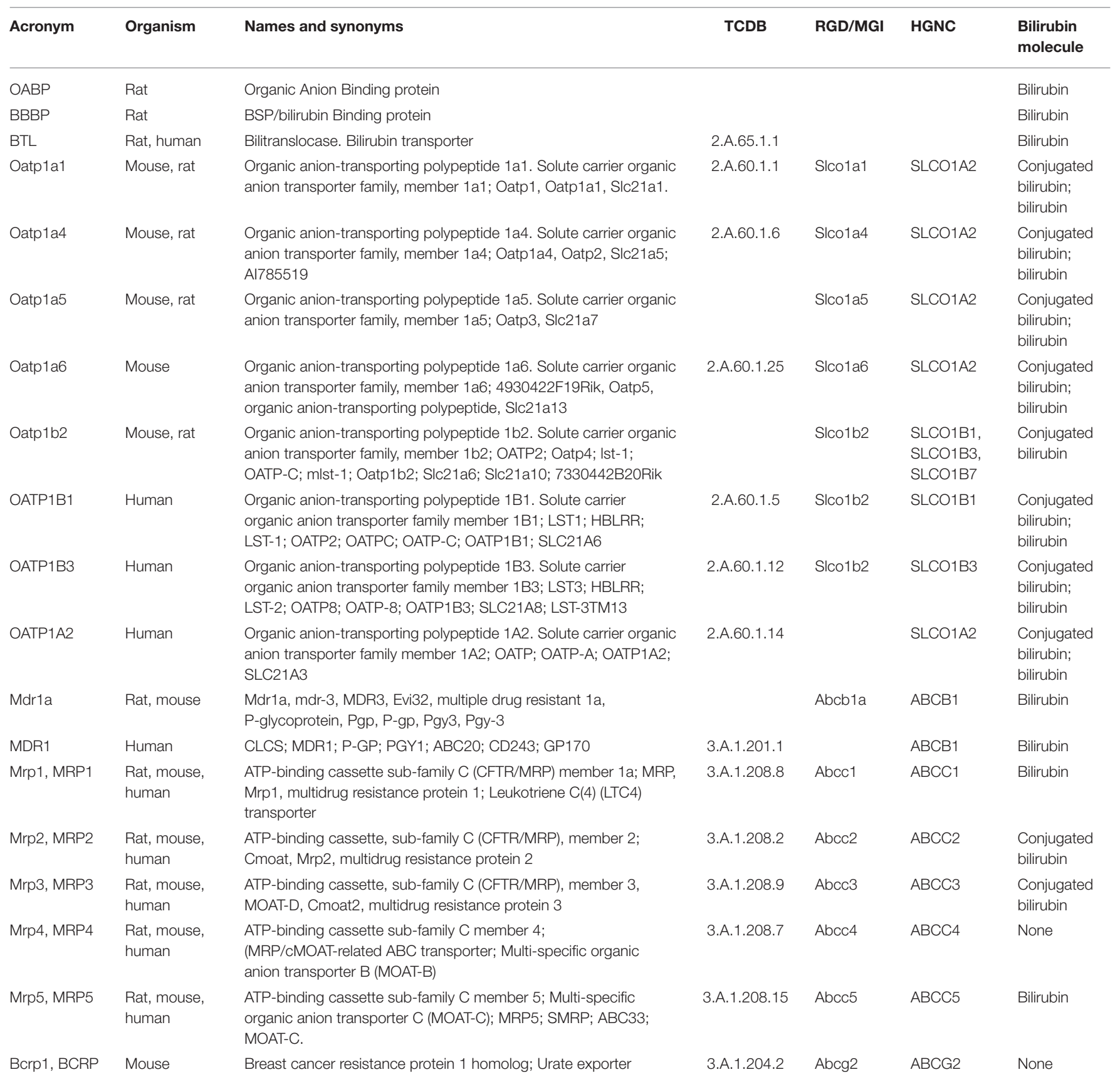

Transporters are identified by codes of the TCDB, Transporter Classification Database; RGD, The Rat Genome Database; MGI, The Mouse Genome Database; HGNC, The HUGO Gene Nomenclature Committee.

gland confers the phenotype of depositing blue-shelled eggs, as a result of inclusion of biliverdin in the shell (Wang et al., 2013; Wragg et al., 2013). It may be therefore speculated that OATP1B3 may take part in the rapid and trans-compartmental (blood-liver) redox equilibrium of BR/biliverdin. The occurrence of the BR/biliverdin pair in human serum could be detected by advanced analytics (Martelanc et al., 2016).

Hence, UCB uptake into the liver must certainly result from redundancy and complementation of multiple membrane transporters, as it is for enzymes (Pandya et al., 2014). The synopsis in Table 5 shows indeed pieces of redundancy.

The membrane transporter bilitranslocase (BTL) has been characterized as a BR transporter in plasma membrane vesicles, where it has been kinetically characterized by the electrogenic BSP transport assay (Passamonti et al., 2010), with UCB as a competitive inhibitor $\left(\mathrm{K}_{\mathrm{i}}=0.11 \mu \mathrm{M}\right)$ (Passamonti et al., 2005a). Time-dependent inhibition by either protein reagents or affinitypurified, anti-sequence antibodies showed that bilitranslocase has 
at least two apparent, high-affinity BR binding sites $\left(\mathrm{K}_{\mathrm{i}}=0.3\right.$ and $2 \mathrm{nM}$, respectively), located on extracellular domains of the protein and both targeted by 2 different anti-sequence antibodies (Battiston et al., 1998; Passamonti et al., 2005a). One of these antibodies inhibited cellular uptake of BR, added at $50 \mathrm{nM}$ in an albumin-free solution (Passamonti et al., 2005b). It should be stressed that the electrogenic BSP transport assay measures the activity of a BSP transporter completely different from any other SLC transporter, as assessed by an extensive functional characterization of its competitive and noncompetitive inhibitors (Zuperl et al., 2011) and as confirmed by BSP uptake tests in rat and human liver slices (Terdoslavich et al., 2012).

The troubled question about this transporter is its gene, which has not yet been characterized, as well as its mRNA, which corresponds to a large segment of the anti-sense strand of the gene that encodes for caeruloplasmin (Battiston et al., 1998; Passamonti et al., 2009) and follows therefore the unpredictable fate of sense-antisense RNA pairs. Yet, by applying a package of highly sophisticated computational approaches (Venko et al., 2017), the bilitranslocase primary structure was turned into a $3 \mathrm{D}$ membrane protein model that comprises 4 trans-membrane domains (Roy Choudhury et al., 2013), 2 of which interact and both are able to make a synergistic kink in the middle of the membrane, providing a theoretical structural requirement for substrate translocation (Roy Choudhury et al., 2015).

Both OATP1B1 (Wang et al., 2005; Mandery et al., 2012) and bilitranslocase (Passamonti et al., 2002; Karawajczyk et al., 2007) have the demonstrated capacity to transport dietary flavonoids that, by transport competition, may intermittently interfere with the fine blood-liver equilibrium of BR. It is obvious therefore that multiple, membrane transporters for UCB must coexist and

\section{REFERENCES}

Adachi, Y., Roy-Chowdhury, J., Roy-Chowdhury, N., Kinne, R., Tran, T., Kobayashi, H., et al. (1990). Hepatic uptake of bilirubin diglucuronide: analysis by using sinusoidal plasma membrane vesicles. J. Biochem. 107, 749-754. doi: 10.1093/oxfordjournals.jbchem.a123120

Battiston, L., Passamonti, S., Macagno, A., and Sottocasa, G. L. (1998). The bilirubin-binding motif of bilitranslocase and its relation to conserved motifs in ancient biliproteins. Biochem. Biophys. Res. Commun. 247, 687-692. doi: 10.1006/bbrc.1998.8868

Belinsky, M. G., Dawson, P. A., Shchaveleva, I., Bain, L. J., Wang, R., Ling, V., et al. (2005). Analysis of the in vivo functions of Mrp3. Mol. Pharmacol. 68, 160-168. doi: 10.1124/mol.104.010587

Billing, B. H., and Black, M. (1969). Bilirubin metabolism. Gut 10, 250-254. doi: 10.1136/gut.10.4.250

Blake, J. A., Eppig, J. T., Kadin, J. A., Richardson, J. E., Smith, C. L., Bult, C. J., et al. (2017). Mouse Genome Database (MGD)-2017: community knowledge resource for the laboratory mouse. Nucleic Acids Res. 45, D723D729. doi: 10.1093/nar/gkw1040

Bloomer, J. R., and Zaccaria, J. (1976). Effect of graded bilirubin loads on bilirubin transport by perfused rat liver. Am. J. Physiol. 230, 736-742.

Brandoni, A., Hazelhoff, M. H., Bulacio, R. P., and Torres, A. M. (2012). Expression and function of renal and hepatic organic anion transporters in extrahepatic cholestasis. World J. Gastroenterol. 18:6387. doi: 10.3748/wjg.v18.i44.6387

Briz, O., Serrano, M. A., MacIas, R. I. R., Gonzalez-Gallego, J., and Marin, J. J. G. (2003). Role of organic anion-transporting polypeptides, OATP-A, OATP-C concur to rapid and rate-unlimited BR uptake into the liver. It may be that the other BR-binding proteins in the list of Table 3, i.e., OABP (Wolkoff, 2014) and BBBP (Brandoni et al., 2012), or additional ones yet to discover, may contribute to BR uptake into the liver.

\section{CONCLUSIONS}

This is the first systematic review of experimental studies on membrane transporters for BR and its conjugates. We selected 44 articles reporting in vitro and in vivo studies published from 1980 to July 2017. They reported about 11 electrochemical potential-driven and 8 primary active membrane transporters. Paradoxically, the remarkable advancements in this field have only confirmed the elusive mechanism(s) enabling UCB to diffuse into the liver as if no cellular boundary existed.

\section{AUTHOR CONTRIBUTIONS}

SP designed the method, while JČ implemented and refined it. JČ created and managed the database of the PubMed search output, and the study features. SP and JČ independently screened and assessed the included articles. SP drafted the manuscript and JC refined both the text and the database. JC prepared tables and the figure.

\section{FUNDING}

This study has been supported by the TRANS2CARE project (CB101), funded by the Cross-border Cooperation Programme Italy-Slovenia 2007-2013 (European Regional Development Fund and National Funds). and OATP-8, in the human placenta-maternal liver tandem excretory pathway for foetal bilirubin. Biochem. J. 371, 897-905. doi: 10.1042/bj20030034

Burra, P., and Masier, A. (2004). Dynamic tests to study liver function. Eur. Rev. Med. Pharmacol. Sci. 8, 19-21.

Calligaris, S., Cekic, D., Roca-Burgos, L., Gerin, F., Mazzone, G., Ostrow, J. D., et al. (2006). Multidrug resistance associated protein 1 protects against bilirubin-induced cytotoxicity. FEBS Lett. 580, 1355-1359. doi: 10.1016/j.febslet.2006.01.056

Chen, C., Stock, J. L., Liu, X., Shi, J., Van Deusen, J. W., DiMattia, D. A., et al. (2008). Utility of a novel Oatp1b2 knockout mouse model for evaluating the role of Oatp1b2 in the hepatic uptake of model compounds. Drug Metab. Dispos. 36, 1840-1845. doi: 10.1124/dmd.108.020594

Chu, X., Shih, S.-J., Shaw, R., Hentze, H., Chan, G. H., Owens, K., et al. (2015). Evaluation of cynomolgus monkeys for the identification of endogenous biomarkers for hepatic transporter inhibition and as a translatable model to predict pharmacokinetic interactions with statins in humans. Drug Metab. Dispos. 43, 851-863. doi: 10.1124/dmd.115.063347

Chu, X.-Y., Strauss, J. R., Mariano, M. A., Li, J., Newton, D. J., Cai, X., et al. (2006). Characterization of mice lacking the multidrug resistance protein MRP2 (ABCC2). J. Pharmacol. Exp. Ther. 317, 579-589. doi: 10.1124/jpet.105.098665

Cui, Y., König, J., Leier, I., Buchholz, U., and Keppler, D. (2001). Hepatic uptake of bilirubin and its conjugates by the human organic anion transporter SLC21A6. J. Biol. Chem. 276, 9626-9630. doi: 10.1074/jbc.M004968200

de Waart, D. R., Naik, J., Utsunomiya, K. S., Duijst, S., Ho-Mok, K., Bolier, A. R., et al. (2016). ATP11C targets basolateral bile salt transporter proteins in mouse central hepatocytes. Hepatology 64, 161-174. doi: 10.1002/hep.28522 
Erlinger, S., Arias, I. M., and Dhumeaux, D. (2014). Inherited disorders of bilirubin transport and conjugation: new insights into molecular mechanisms and consequences. Gastroenterology 146, 1625-1638. doi: 10.1053/j.gastro.2014.03.047

Franko, M. (2008). Thermal lens spectrometric detection in flow injection analysis and separation techniques. Appl. Spectrosc. Rev. 43, 358-388. doi: $10.1080 / 05704920802108032$

Goeser, T., Nakata, R., Braly, L. F., Sosiak, A., Campbell, C. G., Dermietzel, R., et al. (1990). The rat hepatocyte plasma membrane organic anion binding protein is immunologically related to the mitochondrial $\mathrm{F} 1$ adenosine triphosphatase beta-subunit. J. Clin. Invest. 86, 220-227. doi: 10.1172/JCI114687

Gong, L., Aranibar, N., Han, Y.-H., Zhang, Y., Lecureux, L., Bhaskaran, V., et al. (2011). Characterization of organic anion-transporting polypeptide (Oatp) la1 and 1a4 null mice reveals altered transport function and urinary metabolomic profiles. Toxicol. Sci. 122, 587-597. doi: 10.1093/toxsci/kfr114

Goresky, C. A. (1965). The hepatic uptake and excretion of sulfobromophthalein and bilirubin. Can. Med. Assoc. J. 92, 851-857.

Gray, K. A., Yates, B., Seal, R. L., Wright, M. W., and Bruford, E. A. (2015). Genenames.org: the HGNC resources in 2015. Nucleic Acids Res. 43, D1079D1085. doi: 10.1093/nar/gku1071

Hagenbuch, B., and Stieger, B. (2013). The SLCO (former SLC21) superfamily of transporters. Mol. Aspects Med. 34, 396-412. doi: 10.1016/j.mam.2012.10.009

Hankø, E., Tommarello, S., Watchko, J. F., and Hansen, T. W. R. (2003). Administration of drugs known to inhibit P-glycoprotein increases brain bilirubin and alters the regional distribution of bilirubin in rat brain. Pediatr. Res. 54, 441-445. doi: 10.1203/01.PDR.0000085169.87948.B6

Hayashi, H., Mizuno, T., Horikawa, R., Nagasaka, H., Yabuki, T., Takikawa, H., et al. (2012). 4-Phenylbutyrate modulates ubiquitination of hepatocanalicular MRP2 and reduces serum total bilirubin concentration. J. Hepatol. 56, 1136-1144. doi: 10.1016/j.jhep.2011.11.021

Hirouchi, M., Suzuki, H., and Sugiyama, Y. (2005). Treatment of hyperbilirubinemia in Eisai hyperbilirubinemic rat by transfecting human MRP2/ABCC2 gene. Pharm. Res. 22, 661-666. doi: 10.1007/s11095-005-2502-1

Hunton, D. B., Bollman, J. L., and Hoffman, H. N. II. (1961). The plasma removal on indocyanine green and sulfobromophthalein: effect of dosage and blocking agents. J. Clin. Invest. 40, 1648-1655. doi: 10.1172/JCI104387

Itani, T., Kobayashi, Y., Kuroda, M., Ma, N., Mifuji, R., Urawa, N., et al. (2005). Transfecting the multidrug resistance protein 2 gene improves transcellular organic anion transport. Int. J. Mol. Med. 16, 821-825. doi: 10.3892/ijmm.16.5.821

Jacobsen, J., and Brodersen, R. (1983). Albumin-bilirubin binding mechanism. J. Biol. Chem. 258, 6319-6326.

Jacquemin, E., Hagenbuch, B., Stieger, B., Wolkoff, A. W., and Meier, P. J. (1994). Expression cloning of a rat liver $\mathrm{Na}(+)$-independent organic anion transporter. Proc. Natl. Acad. Sci. U.S.A. 91, 133-137. doi: 10.1073/pnas.91.1.133

Jedlitschky, G., Leier, I., Buchholz, U., Hummel-Eisenbeiss, J., Burchell, B., and Keppler, D. (1997). ATP-dependent transport of bilirubin glucuronides by the multidrug resistance protein MRP1 and its hepatocyte canalicular isoform MRP2. Biochem. J. 327, 305-310. doi: 10.1042/bj3270305

Kamisako, T., Leier, I., Cui, Y., Konig, J., Buchholz, U., Hummel-Eisenbeiss, J., et al. (1999). Transport of monoglucuronosyl and bisglucuronosyl bilirubin by recombinant human and rat multidrug resistance protein 2. Hepatology 30 , 485-490. doi: 10.1002/hep.510300220

Kapitulnik, J., and Maines, M. D. (2012). The role of bile pigments in health and disease: effects on cell signaling, cytotoxicity, and cytoprotection. Front. Pharmacol. 3:136. doi: 10.3389/fphar.2012.00136

Karawajczyk, A., Drgan, V., Medic, N., Oboh, G., Passamonti, S., and Novič, M. (2007). Properties of flavonoids influencing the binding to bilitranslocase investigated by neural network modelling. Biochem. Pharmacol. 73, 308-320. doi: $10.1016 /$ j.bcp.2006.09.024

Kawaguchi, A., Nozaki, Y., Hosokawa, S., Tagaya, O., Mikami, T., and Wakabayashi, T. (1994). Establishment of hyperbilirubinuria rat mutant-a new animal model for jaundice. Exp. Anim. 43, 37-44. doi: 10.1538/expanim1978.43.1_37

Keppler, D. (2014). The roles of MRP2, MRP3, OATP1B1, and OATP1B3 in conjugated hyperbilirubinemia. Drug Metab. Dispos. 42, 561-565. doi: $10.1124 / \mathrm{dmd} .113 .055772$
König, J., Cui, Y., Nies, A. T., and Keppler, D. (2000). A novel human organic anion transporting polypeptide localized to the basolateral hepatocyte membrane. Am. J. Physiol. Liver Physiol. 278, G156-G164.

Kotsampasakou, E., Escher, S. E., and Ecker, G. F. (2017a). Curated human hyperbilirubinemia data and the respective OATP1B1 and 1B3 inhibition predictions. Data Brief 11, 204-207. doi: 10.1016/j.dib.2017.02.009

Kotsampasakou, E., Escher, S. E., and Ecker, G. F. (2017b). Linking organic anion transporting polypeptide 1B1 and 1B3 (OATP1B1 and OATP1B3) interaction profiles to hepatotoxicity - the hyperbilirubinemia use case. Eur. J. Pharm. Sci. 100, 9-16. doi: 10.1016/j.ejps.2017.01.002

Lee, Y.-M. A., Cui, Y., König, J., Risch, A., Jäger, B., Drings, P., et al (2004). Identification and functional characterization of the natural variant MRP3-Arg1297His of human multidrug resistance protein 3 (MRP3/ABCC3). Pharmacogenetics 14, 213-223. doi: 10.1097/00008571-200404000-00001

Levitt, D. G., and Levitt, M. D. (2014). Quantitative assessment of the multiple processes responsible for bilirubin homeostasis in health and disease. Clin. Exp. Gastroenterol. 7, 307-328. doi: 10.2147/CEG.S64283

Lu, H., Choudhuri, S., Ogura, K., Csanaky, I. L., Lei, X., Cheng, X., et al. (2008). Characterization of organic anion transporting polypeptide $1 \mathrm{~b} 2$-null mice: essential role in hepatic uptake/toxicity of phalloidin and microcystin-LR. Toxicol. Sci. 103, 35-45. doi: 10.1093/toxsci/kfn038

Maestro, A., Terdoslavich, M., Vanzo, A., Kuku, A., Tramer, F., Nicolin, V., et al. (2010). Expression of bilitranslocase in the vascular endothelium and its function as a flavonoid transporter. Cardiovasc. Res. 85, 175-183. doi: $10.1093 / \mathrm{cvr} / \mathrm{cvp} 290$

Maher, J. M., Aleksunes, L. M., Dieter, M. Z., Tanaka, Y., Peters, J. M., Manautou, J. E., et al. (2008). Nrf2- and PPAR $\alpha$-mediated regulation of hepatic mrp transporters after exposure to perfluorooctanoic acid and perfluorodecanoic acid. Toxicol. Sci. 106, 319-328. doi: 10.1093/toxsci/kfn177

Mandery, K., Balk, B., Bujok, K., Schmidt, I., Fromm, M. F., and Glaeser, H. (2012). Inhibition of hepatic uptake transporters by flavonoids. Eur. J. Pharm. Sci. 46, 79-85. doi: 10.1016/j.ejps.2012.02.014

Mangiullo, R., Gnoni, A., Leone, A., Gnoni, G. V., Papa, S., and Zanotti, F. (2008). Structural and functional characterization of $\mathrm{F}(\mathrm{o}) \mathrm{F}(1)$-ATP synthase on the extracellular surface of rat hepatocytes. Biochim. Biophys. Acta 1777, 1326-1335. doi: 10.1016/j.bbabio.2008.08.003

Martelanc, M., Žiberna, L., Passamonti, S., and Franko, M. (2016). Application of high-performance liquid chromatography combined with ultra-sensitive thermal lens spectrometric detection for simultaneous biliverdin and bilirubin assessment at trace levels in human serum. Talanta 154, 92-98. doi: 10.1016/j.talanta.2016.03.053

Matsushima, A., Oda, K., Mori, N., and Murakami, T. (2017). Modulation of multidrug resistance-associated proteins function in erythrocytes in glycerol-induced acute renal failure rats. J. Pharm. Pharmacol. 69, 172-181. doi: $10.1111 /$ jphp. 12664

McDonagh, A. F. (2008). Photolysis and photoisomerization of bilirubin in serum specimens exposed to room lighting. Clin. Chim. Acta. 393:130. doi: 10.1016/j.cca.2008.03.005

Mennone, A., Soroka, C. J., Cai, S., Harry, K., Adachi, M., Hagey, L., et al. (2006). Mrp4-/- mice have an impaired cytoprotective response in obstructive cholestasis. Hepatology 43, 1013-1021. doi: 10.1002/hep.21158

Mennone, A., Soroka, C. J., Harry, K. M., and Boyer, J. L. (2010). Role of breast cancer resistance protein in the adaptive response to cholestasis. Drug Metab. Dispos. 38, 1673-1678. doi: 10.1124/dmd.110.034512

Mooij, M. G., Schwarz, U. I., de Koning, B. A. E., Leeder, J. S., Gaedigk, R., Samsom, J. N., et al. (2014). Ontogeny of human hepatic and intestinal transporter gene expression during childhood: age matters. Drug Metab. Dispos. 42, 1268-1274. doi: 10.1124/dmd.114.056929

Nakanishi, T., Ikenaga, M., Fukuda, H., Matsunaga, N., and Tamai, I. (2012). Application of quantitative time-lapse imaging (QTLI) for evaluation of Mrp2based drug-drug interaction induced by liver metabolites. Toxicol. Appl. Pharmacol. 263, 244-250. doi: 10.1016/j.taap.2012.06.016

Nakatani, T., Sakamoto, Y., Ando, H., and Kobayashi, K. (1995). Bile and bilirubin excretion in relation to hepatic energy status hemorrhagic shock and hypoxemia in rabbits. J. Trauma Acute Care Surg. 39, 665-670.

Narvaiza, I., Aparicio, O., Vera, M., Razquin, N., Bortolanza, S., Prieto, J., et al. (2006). Effect of adenovirus-mediated RNA interference on endogenous 
microRNAs in a mouse model of multidrug resistance protein 2 gene silencing. J. Virol. 80, 12236-12247. doi: 10.1128/JVI.01205-06

Nishiya, T., Kataoka, H., Mori, K., Goto, M., Sugawara, T., and Furuhama, K. (2006). Tienilic acid enhances hyperbilirubinemia in eisai hyperbilirubinuria rats through hepatic multidrug resistance-associated protein 3 and heme oxygenase-1 induction. Toxicol. Sci. 91, 651-659. doi: 10.1093/toxsci/kfj162

Pandya, C., Farelli, J. D., Dunaway-Mariano, D., and Allen, K. N. (2014). Enzyme promiscuity: engine of evolutionary innovation. J. Biol. Chem. 289, 30229-30236. doi: 10.1074/jbc.R114.572990

Pascolo, L., Fernetti, C., Garcia-Mediavilla, M. V., Ostrow, J. D., and Tiribelli, C. (2001). Mechanisms for the transport of unconjugated bilirubin in human trophoblastic BeWo cells. FEBS Lett. 495, 94-99. doi: 10.1016/S0014-5793(01)02357-2

Passamonti, S., Battiston, L., and Sottocasa, G. L. (1997). Arylsulfonylation of bilitranslocase in plasma membranes from rat liver enables to discriminate between natural and artificial substrates. Biochim. Biophys. Acta 1323, 130-136. doi: 10.1016/S0005-2736(96)00181-2

Passamonti, S., Cocolo, A., Braidot, E., Petrussa, E., Peresson, C., Medic, N., et al. (2005a). Characterization of electrogenic bromosulfophthalein transport in carnation petal microsomes and its inhibition by antibodies against bilitranslocase. FEBS J. 272, 3282-3296. doi: 10.1111/j.1742-4658.2005.04751.x

Passamonti, S., and Sottocasa, G. L. (1990). The sulfhydryl groups responsible for bilitranslocase transport activity respond to the interaction of the carrier with bilirubin and functional analogues. Biochim. Biophys. Acta 1021, 9-12. doi: 10.1016/0005-2736(90)90376-Y

Passamonti, S., Terdoslavich, M., Franca, R., Vanzo, A., Tramer, F., Braidot, E., et al. (2009). Bioavailability of flavonoids: a review of their membrane transport and the function of bilitranslocase in animal and plant organisms. Curr. Drug Metab. 10, 369-394. doi: 10.2174/138920009788498950

Passamonti, S., Terdoslavich, M., Margon, A., Cocolo, A., Medic, N., Micali, F., et al. (2005b). Uptake of bilirubin into HepG2 cells assayed by thermal lens spectroscopy: Function of bilitranslocase. FEBS J. 272, 5522-5535. doi: $10.1111 / j .1742-4658.2005 .04949 . x$

Passamonti, S., Tramer, F., Petrussa, E., Braidot, E., and Vianello, A. (2010). Electrogenic bromosulfalein transport in isolated membrane vesicles: implementation in both animal and plant preparations for the study of flavonoid transporters. Methods Mol. Biol. 643, 307-335. doi: 10.1007/978-1-60761-723-5_21

Passamonti, S., Vrhovsek, U., and Mattivi, F. (2002). The interaction of anthocyanins with bilitranslocase. Biochem. Biophys. Res. Commun. 296, 631-636. doi: 10.1016/S0006-291X(02)00927-0

Rigato, I., Pascolo, L., Fernetti, C., Ostrow, J. D., and Tiribelli, C. (2004). The human multidrug-resistance-associated protein MRP1 mediates ATPdependent transport of unconjugated bilirubin. Biochem. J. 383, 335-341. doi: 10.1042/BJ20040599

Roy Choudhury, A., Perdih, A., Zuperl, S., Sikorska, E., Solmajer, T., Jurga, S., et al. (2013). Structural elucidation of transmembrane transporter protein bilitranslocase: conformational analysis of the second transmembrane region TM2 by molecular dynamics and NMR spectroscopy. Biochim. Biophys. Acta 1828, 2609-2619. doi: 10.1016/j.bbamem.2013.06.006

Roy Choudhury, A., Sikorska, E., van den Boom, J., Bayer, P., Popenda, L., Szutkowski, K., et al. (2015). Structural model of the bilitranslocase transmembrane domain supported by NMR and FRET data. PLOS ONE 10:e0135455. doi: 10.1371/journal.pone.0135455

Saier, M. H. J., Reddy, V. S., Tsu, B. V., Ahmed, M. S., Li, C., and Moreno-Hagelsieb, G. (2016). The Transporter Classification Database (TCDB): recent advances. Nucleic Acids Res. 44, D372-D379. doi: 10.1093/nar/gkv1103

Sanna, S., Busonero, F., Maschio, A., McArdle, P. F., Usala, G., Dei, M., et al. (2009). Common variants in the SLCO1B3 locus are associated with bilirubin levels and unconjugated hyperbilirubinemia. Hum. Mol. Genet. 18, 2711-2718. doi: $10.1093 / \mathrm{hmg} / \mathrm{ddp} 203$

Scharschmidt, B. F., Waggoner, J. G., and Berk, P. D. (1975). Hepatic organic anion uptake in the rat. J. Clin. Invest. 56, 1280-1292. doi: 10.1172/JCI108204

Scheer, N., Balimane, P., Hayward, M. D., Buechel, S., Kauselmann, G., and Wolf, C. R. (2012). Generation and characterization of a novel multidrug resistance protein 2 humanized mouse line. Drug Metab. Dispos. 40, 2212-2218. doi: $10.1124 / \mathrm{dmd} .112 .047605$
Shamseer, L., Moher, D., Clarke, M., Ghersi, D., Liberati, A., Petticrew, M., et al. (2015). Preferred reporting items for systematic review and meta-analysis protocols (PRISMA-P) 2015: elaboration and explanation. BMJ 349:g7647. doi: $10.1136 /$ bmj.g7647

Shimoyama, M., De Pons, J., Hayman, G. T., Laulederkind, S. J. F., Liu, W., Nigam, R., et al. (2015). The rat genome database 2015: genomic, phenotypic and environmental variations and disease. Nucleic Acids Res. 43, D743-D750. doi: $10.1093 /$ nar/gku1026

Skierka, J. M., Kotzer, K. E., Lagerstedt, S. A., O'Kane, D. J., and Baudhuin, L. M. (2013). UGT1A1 genetic analysis as a diagnostic aid for individuals with unconjugated hyperbilirubinemia. J. Pediatr. 162, 1146-1152. doi: 10.1016/j.jpeds.2012.11.042

Sticova, E., and Jirsa, M. (2013). New insights in bilirubin metabolism and their clinical implications. World J. Gastroenterol. 19, 6398-6407. doi: 10.3748/wjg.v19.i38.6398

Stieger, B., and Hagenbuch, B. (2014). Organic anion transporting polypeptides. Curr. Top. Membr. 73, 205-232. doi: 10.1016/B978-0-12-800223-0.00005-0

Stollman, Y. R., Gartner, U., Theilmann, L., Ohmi, N., and Wolkoff, A. W. (1983). Hepatic bilirubin uptake in the isolated perfused rat liver is not facilitated by albumin binding. J. Clin. Invest. 72, 718-723. doi: 10.1172/JCI111021

St-Pierre, M. V., Serrano, M. A., Macias, R. I., Dubs, U., Hoechli, M., Lauper, U., et al. (2000). Expression of members of the multidrug resistance protein family in human term placenta. Am. J. Physiol. Regul. Integr. Comp. Physiol. 279, R1495-R1503.

Stremmel, W., and Diede, H. E. (1990). Cellular uptake of conjugated bilirubin and sulfobromophthalein (BSP) by the human hepatoma cell line Hep G2 is mediated by a membrane BSP/bilirubin binding protein. J. Hepatol. 10, 99-104. doi: 10.1016/0168-8278(90)90079-7

Stremmel, W., Gerber, M. A., Glezerov, V., Thung, S. N., Kochwa, S., and Berk, P. D. (1983). Physicochemical and immunohistological studies of a sulfobromophthalein-and bilirubin-binding protein from rat liver plasma membranes. J. Clin. Invest. 71, 1796-1805. doi: 10.1172/JCI110935

Terdoslavich, M., de Graaf, I. A. M., Proost, J. H., Cocolo, A., Passamonti, S., and Groothuis, G. M. M. (2012). Bilitranslocase is involved in the uptake of bromosulfophthalein in rat and human liver. Drug Metab. Lett. 6, 165-173. doi: $10.2174 / 1872312811206030003$

Tiribelli, C., Lunazzi, G., Luciani, M., Panfili, E., Gazzin, B., Liut, G., et al. (1978). Isolation of a sulfobromophthalein-binding protein from hepatocyte plasma membrane. Biochim. Biophys. Acta 532, 105-112. doi: 10.1016/0005-2795(78)90453-1

Torres, A. M., Lunazzi, G. C., Stremmel, W., and Tiribelli, C. (1993). Bilitranslocase and sulfobromophthalein/bilirubin-binding protein are both involved in the hepatic uptake of organic anions. Proc. Natl. Acad. Sci. U.S.A. 90, 8136-8139. doi: $10.1073 /$ pnas. 90.17 .8136

van de Steeg, E., Stránecký, V., Hartmannová, H., Nosková, L., Hrebíček, M., Wagenaar, E., et al. (2012). Complete OATP1B1 and OATP1B3 deficiency causes human Rotor syndrome by interrupting conjugated bilirubin reuptake into the liver. J. Clin. Invest. 122, 519-528. doi: 10.1172/JCI 59526

van de Steeg, E., van Esch, A., Wagenaar, E., Kenworthy, K. E., and Schinkel, A. H. (2013). Influence of human OATP1B1, OATP1B3, and OATP1A2 on the pharmacokinetics of methotrexate and paclitaxel in humanized transgenic mice. Clin. Cancer Res. 19, 821-832. doi: 10.1158/1078-0432.CCR$12-2080$

van de Steeg, E., Wagenaar, E., van der Kruijssen, C. M. M., Burggraaff, J. E. C., de Waart, D. R., Elferink, R. P. J. O., et al. (2010). Organic anion transporting polypeptide $1 \mathrm{a} / 1 \mathrm{~b}-$ knockout mice provide insights into hepatic handling of bilirubin, bile acids, and drugs. J. Clin. Invest. 120, 2942-2952. doi: 10.1172/JCI42168

Vanwijngaerden, Y., Wauters, J., Langouche, L., Vander Perre, S., Liddle, C. Coulter, S., et al. (2011). Critical illness evokes elevated circulating bile acids related to altered hepatic transporter and nuclear receptor expression. Hepatology 54, 1741-1752. doi: 10.1002/hep.24582

Venko, K., Roy Choudhury, A., and Novic, M. (2017). Computational approaches for revealing the structure of membrane transporters: case study on bilitranslocase. Comput. Struct. Biotechnol. J. 15, 232-242. doi: $10.1016 /$ j.csbj.2017.01.008 
Vlaming, M. L. H., Pala, Z., van Esch, A., Wagenaar, E., de Waart, D. R., van de Wetering, K., et al. (2009). Functionally overlapping roles of Abcg2 (Bcrp1) and Abcc2 (Mrp2) in the elimination of methotrexate and its main toxic metabolite 7-hydroxymethotrexate in vivo. Clin. Cancer Res. 15, 3084-3093. doi: 10.1158/1078-0432.CCR-08-2940

Wang, P., Kim, R. B., Chowdhury, J. R., and Wolkoff, A. W. (2003). The human organic anion transport protein SLC21A6 is not sufficient for bilirubin transport. J. Biol. Chem. 278, 20695-20699. doi: 10.1074/jbc.M301100200

Wang, X., Chowdhury, J. R., and Chowdhury, N. R. (2006). Bilirubin metabolism: applied physiology. Curr. Paediatr. 16, 70-74. doi: 10.1016/j.cupe.2005.10.002

Wang, X., Wolkoff, A. W., and Morris, M. E. (2005). Flavonoids as a novel class of human organic anion-transporting polypeptide OATP1B1 (OATP-C) modulators. Drug Metab. Dispos. 33, 1666-1672. doi: 10.1124/dmd.105.005926

Wang, Z., Qu, L., Yao, J., Yang, X., Li, G., Zhang, Y., et al. (2013). An EAV-HP insertion in $5^{\prime}$ flanking region of SLCO1B3 causes blue eggshell in the chicken. PLoS Genet. 9:e1003183. doi: 10.1371/journal.pgen.1003183

Watanabe, T., Miyake, M., Shimizu, T., Kamezawa, M., Masutomi, N., Shimura, T., et al. (2015). Utility of bilirubins and bile acids as endogenous biomarkers for the inhibition of hepatic transporters. Drug Metab. Dispos. 43, 459-466. doi: 10.1124/dmd.114.061051

Watchko, J. F., Daood, M. J., and Hansen, T. W. R. (1998). Brain bilirubin content is increased in P-glycoprotein-deficient transgenic null mutant mice. Pediatr. Res. 44, 763-766. doi: 10.1203/00006450-199811000-00020

Wolkoff, A. W. (2014). Organic anion uptake by hepatocytes. Compr. Physiol. 4, 1715-1735. doi: 10.1002/cphy.c140023

Wolkoff, A. W., and Chung, C. T. (1980). Identification, purification, and partial characterization of an organic anion binding protein from rat liver cell plasma membrane. J. Clin. Invest. 65, 1152-1161. doi: 10.1172/JCI109770

Wragg, D., Mwacharo, J. M., Alcalde, J. A., Wang, C., Han, J.-L., Gongora, J., et al. (2013). Endogenous retrovirus EAV-hp linked to blue egg phenotype in mapuche fowl. PLoS ONE 8:e71393. doi: 10.1371/journal.pone.00 71393

Zaher, H., zu Schwabedissen, H. E. M., Tirona, R. G., Cox, M. L., Obert, L. A., Agrawal, N., et al. (2008). Targeted disruption of murine organic aniontransporting polypeptide $1 \mathrm{~b} 2$ (Oatp1b2/Slco1b2) significantly alters disposition of prototypical drug substrates pravastatin and rifampin. Mol. Pharmacol. 74, 320-329. doi: 10.1124/mol.108.046458

Zelcer, N., van de Wetering, K., de Waart, R., Scheffer, G. L., Marschall, H.-U., Wielinga, P. R., et al. (2006). Mice lacking Mrp3 (Abcc3) have normal bile salt transport, but altered hepatic transport of endogenous glucuronides. J. Hepatol. 44, 768-775. doi: 10.1016/j.jhep.2005.07.022

Zhang, W., He, Y.-J., Gan, Z., Fan, L., Li, Q., Wang, A., et al. (2007). OATP1B1 polymorphism is a major determinant of serum bilirubin level but not associated with rifampicin-mediated bilirubin elevation. Clin. Exp. Pharmacol. Physiol. 34, 1240-1244. doi: 10.1111/j.1440-1681.2007. 04798.x

Zuperl, S., Fornasaro, S., Novic, M., and Passamonti, S. (2011). Experimental determination and prediction of bilitranslocase transport activity. Anal. Chim. Acta 705, 322-333. doi: 10.1016/j.aca.2011.07.004

Conflict of Interest Statement: The authors declare that the research was conducted in the absence of any commercial or financial relationships that could be construed as a potential conflict of interest.

Copyright (c) 2017 Čvorović and Passamonti. This is an open-access article distributed under the terms of the Creative Commons Attribution License (CC BY). The use, distribution or reproduction in other forums is permitted, provided the original author(s) or licensor are credited and that the original publication in this journal is cited, in accordance with accepted academic practice. No use, distribution or reproduction is permitted which does not comply with these terms. 